\title{
A versatile synthetic methodology for the synthesis of tryptophols
}

\author{
Simon J. Garden, ${ }^{*}$ Rosângela B. da Silva ${ }^{\dagger}$ and Angelo C. Pinto \\ Departamento de Química Orgânica, Instituto de Química, Universidade Federal do Rio de Janeiro, Ilha do Fundão, \\ Rio de Janeiro CEP 21945-970, Brazil
}

Received 25 July 2002; accepted 23 August 2002

\begin{abstract}
Tryptophols have been obtained in high yields by the reduction of 3-substituted-dioxindoles (obtained by the aldol condensation reaction of ketones with isatins or by a modified Knovenagel malonate condensation) using a borane tetrahydrofuran complex. The reported methodology offers distinct advantages over existing methods for the synthesis of these compounds, including consistently greater yields, diastereoselective syntheses and the possibility for the synthesis of a wide range of structurally different tryptophols. The reduction reaction was found to proceed via an intermediate 1,3-diol-oxindole, which was obtained diastereoselectively and, which was subsequently reduced to the corresponding tryptophol. (C) 2002 Elsevier Science Ltd. All rights reserved.
\end{abstract}

\section{Introduction}

The indole nucleus is widespread in both natural and unnatural products. The interest in this skeletal structure is reflected by the numerous methodologies that have been devised and continue to be explored for its synthesis. ${ }^{1}$

Tryptophols are a class of indoles bearing a C-3 hydroxyethyl side chain that may or may not be $\alpha$ - and or $\beta$-substituted. Tryptophol and a number of its derivatives have been isolated from a variety of natural sources. ${ }^{2}$ In addition, some tryptophol derivatives are known to posses biological activity. Esters of 5-methoxytryptophol posses anticholinergic activity, whereas 5-methoxytryptophol and other tryptophols have little or no activity. ${ }^{3}$ The production of tryptophol, by tryptophan metabolism, has been implicated as one of the pathophysiological mechanisms that provoke sleeping sickness upon infection by trypanosomes. ${ }^{4}$ Of pharmaceutical importance is 7-ethyltryptophol as this compound is used for the synthesis of Etodolac, an important non-steroidal anti-inflammatory drug (NSAID). ${ }^{5}$ Whilst 2-phenyl-2-(3-indolyl)-1-ethanol has been used to prepare Pemedolac, a compound that has been found to be one of the most potent analgesics known and that displays anti-inflammatory activity similar to that of Etodolac. ${ }^{6}$

A number of methods have become established for the synthesis of tryptophols though generally these methods present a number of limitations in that they lack generality,

Keywords: isatin; reduction; borane tetrahydrofuran complex; diastereoselective reduction; tryptophol.

* Corresponding author. Tel.: +55-21-2562-7363; fax: +55-21-2562-7256; e-mail: garden@iq.ufrj.br

† Present address: Centro Federal de Educação Tecnológica de Química de Nilópolis, Nilópolis, Rio de Janeiro, Brazil. or yields are variable, or that they require the synthesis of highly reactive intermediates. One of the earliest reports describes the obtention of tryptophol by the yeast fermentation of tryptophan. ${ }^{2 \mathrm{a}}$ A number of years later, Jackson ${ }^{7}$ prepared tryptophol by the reduction of indole acetic acid esters using sodium in ethanol. Since this earlier work, there has been a steady evolution of methodology. The introduction of $\mathrm{LiAlH}_{4}$ resulted in its use in the reduction of ethyl indole oxoacetic acid derivatives ${ }^{8}$ as well as indole acetic acid derivatives. ${ }^{9}$ The less powerful reducing agent $\mathrm{NaBH}_{4}$, has also been successfully employed. ${ }^{6}$ The diastereoselective synthesis of 3-(2-hydroxycyclohexyl)indole using $\mathrm{NaBH}_{4}$ or $\mathrm{Zn}\left(\mathrm{BH}_{4}\right)_{2}$ by reduction of the corresponding ketone was reported by Freter ${ }^{10}$ and by Audia. ${ }^{11}$ Other methods for the synthesis of tryptophols include: the Fischer indole methodology; ${ }^{1 \mathrm{~b}, \mathrm{~d}, 5,8 \mathrm{a}, 12}$ the ring opening of epoxides by indolyl Grignard reagents, ${ }^{13}$ or by a 3-lithioindole; ${ }^{14}$ the reaction of indoles with diols in an autoclave; ${ }^{15}$ or by reaction with epoxides under pressure. ${ }^{16}$ This latter method has been further developed where the use of lanthanide cations was found to be beneficial. ${ }^{17}$ Lithiation of orthoalkylphenylisocyanides and subsequent treatment with epoxides gave moderate yields of the respective tryptophols. ${ }^{18} \mathrm{~N}, \mathrm{~N}$-Diallyl-ortho-iodo- or bromo-anilines undergo metal halogen exchange on reaction with $t$-BuLi at $-78^{\circ} \mathrm{C}$, which upon warming cyclize to the respective lithiomethylindoline which can react with an electrophile to yield 3 -substituted indolines, subsequent oxidation of which yields the respective 3 -substituted indole. ${ }^{19}$ ortho-Iodoanilines have also found use in a synthetic sequence involving a Heck reaction with an acrylate ester, followed by reduction to the cinnamyl alcohol and subsequent rhodium catalysed hydroformylation yielding tryptophol. ${ }^{20}$

An alternative method to the reduction of indolyl derivatives is based upon the reduction of isatin derivatives. Isatin, 
indol-2,3-dione, is an oxidised form of indole that may be regarded as a masked indole or an umpoled indole equivalent. Isatin and indole have complementary C-3 reactivity. Indole readily reacts with electrophiles whereas isatin readily undergoes a range of $\mathrm{C}-\mathrm{C}$ bond forming reactions by nucleophilic attack at $\mathrm{C}-3 .^{21}$ This complementary C-3 reactivity offers a versatile synthetic strategy for the synthesis of indolic compounds. Tacconi ${ }^{22}$ described a two stage reduction of an isatylidene derivative using $\mathrm{NaBH}_{4}$ followed by sodium in propanol to obtain $\alpha$-methyltryptophol in low overall yield. Whilst David and Doucet $^{23}$ as well as Bergman ${ }^{24}$ have shown that the aldol products, obtained by the condensation of a methylketone with an isatin, can be reduced using $\mathrm{LiAlH}_{4}$ to give the corresponding $\alpha$-substituted tryptophol in $40-50 \%$ yield. The use of isatin derivatives for the preparation of 3-hydroxy-2-oxindole acetic acid esters and the subsequent reduction of these compounds using $\mathrm{LiAlH}_{4}$ has been shown to be a general route for the obtention of tryptophols in good to excellent yields $(65-95 \%))^{6,8 a, 25}$

In ongoing investigations from our laboratory, the reduction of isatin derivatives using borane in THF has proved to be a versatile method for the synthesis of indole derivatives. This relatively unknown method was successfully applied to the reduction of $\mathrm{N}$-acylisatin derivatives in excellent yields to give $N$-alkylindoles ${ }^{26}$ and, more recently, to the reduction of 3,3-difluoro-2-oxindole derivatives, where either 3-fluoroindoles or 3,3-difluoroindolines were obtained depending upon electronic effects of substituents on the aromatic ring. ${ }^{27}$ Previous studies on the $\mathrm{BH}_{3} \cdot \mathrm{THF}$ reduction of isatins and or their derivatives include those of Sirowej, ${ }^{28}$ Wierenga and co-workers, ${ }^{29}$ as well as applications to the synthesis of some natural products. ${ }^{13 c, 30}$ On the other hand, refluxing mixtures of $\mathrm{BH}_{3}$. THF and 2-oxindolylacetic acid derivatives in THF yielded the respective indoline ethanols in $43-79 \%$. $^{31}$

The ketone carbonyl of isatin derivatives is susceptible to nucleophilic attack and aldol type condensations are readily performed under a variety of conditions. ${ }^{21}$ It was therefore reasoned that these aldol products should readily undergo reduction with borane in THF to yield tryptophols. The synthetic potential of these compounds may as of yet be unrealised. There are few reports, with the exception of the previously indicated studies on the synthesis of tetrahydropyranoindoles (Etodolac) and some recent examples of asymmetric syntheses, ${ }^{32}$ that investigate this reactivity. Tryptophols can be converted to tryptamines either by a Mitsunubo reaction, ${ }^{11}$ without inversion of configuration of the chiral center, or by Swern oxidation (yielding tryptophones) and subsequent $\mathrm{NaCNBH}_{3}$ reduction in the presence of an amine. ${ }^{13 d, 33}$

\section{Results and discussion}

Our investigation began with the preparation of $\mathbf{2 a}$ by the reaction of isatin (1a) in acetone in the presence of a catalytic quantity of diethylamine. ${ }^{34}$ A solution of freshly prepared borane $(1 \mathrm{M})$ in $\mathrm{THF}^{35}$ (5 equiv.) was then added to a THF solution of $\mathbf{2 a}$ under a nitrogen atmosphere and externally cooled with an ice water bath (Equation 1). Initial

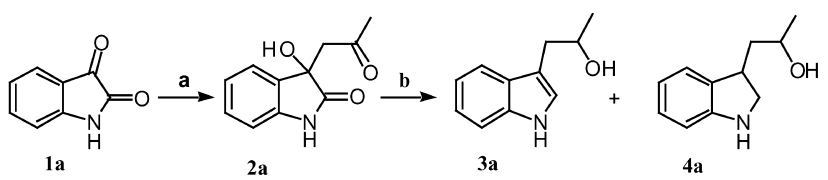

Equation 1. (a) Acetone, $\mathrm{Et}_{2} \mathrm{NH}$ or $\mathrm{K}_{2} \mathrm{CO}_{3}$; (b) $\mathrm{BH}_{3} \cdot \mathrm{THF}$.

reaction, during the addition of borane, resulted in the rapid evolution of hydrogen gas. The reaction was subsequently accompanied by TLC, which readily revealed the formation of a product and the consumption of the starting material over the period of a couple of hours. Isolation of the crude product was achieved by acidic decomposition of the excess borane, followed by neutralisation, extraction, drying of the organic phase and removal of the solvent under reduced pressure. The crude product was obtained as a slightly yellow oil that was subsequently filtered through a short column of silica, using $\mathrm{CH}_{2} \mathrm{Cl}_{2}$ as solvent, to remove baseline (TLC) immobile impurities. Evaporation of the solvent yielded a colourless oil that crystallised on storage. $\mathrm{GC}-\mathrm{MS}$ and ${ }^{1} \mathrm{H} \mathrm{NMR}$ analysis of this product revealed it to be a mixture of the tryptophol 3a contaminated with a small quantity of the respective indoline $4 \mathbf{a}$ (less than 5\%), Equation 1.

Subsequent experiments economised the quantity of borane resulting in the finding that the reaction proceeded equally effectively using only 3 equiv. of borane. GC-MS and ${ }^{1} \mathrm{H}$ NMR analysis of the crude product obtained using 3 equiv. of borane revealed the absence of the indoline $4 \mathbf{a}$. The crude product was purified as described above and the colourless oil crystallised upon storage. The reported literature melting points for 3a are diverse and therefore 3a was characterized analytically and spectroscopically. In experiments using less than 3 equiv. of borane it was found that an incomplete

Table 1. Compounds $\mathbf{2 a}-\mathbf{t}$, substrates for $\mathrm{BH}_{3} \cdot \mathrm{THF}$ reduction

\begin{tabular}{|c|c|c|c|c|c|c|}
\hline Compound & $\mathrm{R}_{1}$ & $\mathrm{R}_{2}$ & $\mathrm{R}_{3}$ & $\mathrm{R}_{4}$ & $\mathrm{R}_{5}$ & $\mathrm{R}_{6}$ \\
\hline $2 \mathbf{a}$ & $\mathrm{H}$ & $\mathrm{H}$ & $\mathrm{H}$ & $\mathrm{H}$ & $\mathrm{H}$ & $\mathrm{Me}$ \\
\hline $2 b$ & $\mathrm{Me}$ & $\mathrm{H}$ & $\mathrm{H}$ & $\mathrm{H}$ & $\mathrm{H}$ & $\mathrm{Me}$ \\
\hline $2 c$ & $\mathrm{H}$ & $\mathrm{H}$ & I & $\mathrm{H}$ & $\mathrm{H}$ & $\mathrm{Me}$ \\
\hline 2d & $\mathrm{H}$ & $\mathrm{H}$ & $\mathrm{NO}_{2}$ & $\mathrm{H}$ & $\mathrm{H}$ & $\mathrm{Me}$ \\
\hline $2 e$ & $\mathrm{H}$ & $\mathrm{Br}$ & $\mathrm{H}$ & $\mathrm{Br}$ & $\mathrm{H}$ & $\mathrm{Me}$ \\
\hline $2 f$ & $\mathrm{H}$ & $\mathrm{H}$ & $\mathrm{Br}$ & $\mathrm{H}$ & $\mathrm{Br}$ & $\mathrm{Me}$ \\
\hline $2 \mathrm{~g}$ & $\mathrm{H}$ & $\mathrm{H}$ & $\mathrm{H}$ & $\mathrm{H}$ & $\mathrm{H}$ & $\mathrm{Ph}$ \\
\hline $2 \mathrm{~h}$ & $\mathrm{H}$ & $\mathrm{Br}$ & $\mathrm{H}$ & $\mathrm{Br}$ & $\mathrm{H}$ & $\mathrm{Ph}$ \\
\hline $2 \mathbf{i}$ & $\mathrm{H}$ & $\mathrm{H}$ & $\mathrm{Br}$ & $\mathrm{H}$ & $\mathrm{Br}$ & $\mathrm{Ph}$ \\
\hline $2 \mathrm{j}$ & $\mathrm{H}$ & $\mathrm{H}$ & $\mathrm{H}$ & $\mathrm{H}$ & $\mathrm{H}$ & a \\
\hline $2 \mathbf{k}$ & $\mathrm{H}$ & $\mathrm{H}$ & $\mathrm{H}$ & $\mathrm{H}$ & $\mathrm{H}$ & $t$-butyl \\
\hline 21 & $\mathrm{Me}$ & $\mathrm{H}$ & $\mathrm{H}$ & $\mathrm{H}$ & $\mathrm{H}$ & $t$-butyl \\
\hline $2 \mathrm{~m}$ & $\mathrm{Bn}$ & $\mathrm{H}$ & $\mathrm{H}$ & $\mathrm{H}$ & $\mathrm{H}$ & $\mathrm{Ph}$ \\
\hline $2 n$ & $\mathrm{H}$ & $\mathrm{H}$ & $\mathrm{H}$ & $\mathrm{H}$ & $\mathrm{H}$ & $\mathrm{CH}(\mathrm{OH}) \mathrm{CH}_{3}{ }^{\mathrm{b}}$ \\
\hline 20 & $\mathrm{H}$ & $\mathrm{H}$ & $\mathrm{H}$ & $\mathrm{H}$ & $\mathrm{H}$ & $\mathrm{CH}(\mathrm{OH}) \mathrm{CH}_{3}{ }^{\mathrm{b}}$ \\
\hline $2 p$ & $\mathrm{H}$ & $\mathrm{H}$ & $\mathrm{H}$ & $\mathrm{H}$ & $\mathrm{H}$ & $\mathrm{CH}(\mathrm{OH}) \mathrm{CH}_{3}{ }^{\mathrm{b}}$ \\
\hline $2 q$ & $\mathrm{Me}$ & $\mathrm{H}$ & $\mathrm{H}$ & $\mathrm{H}$ & $\mathrm{H}$ & $\mathrm{OMe}$ \\
\hline $2 r$ & $\mathrm{Bn}$ & $\mathrm{H}$ & $\mathrm{H}$ & $\mathrm{H}$ & $\mathrm{H}$ & $\mathrm{OMe}$ \\
\hline $2 s$ & $\mathrm{Bn}$ & $\mathrm{H}$ & $\mathrm{H}$ & $\mathrm{H}$ & Et & $\mathrm{OMe}$ \\
\hline $2 t$ & $\mathrm{H}$ & $\mathrm{H}$ & $\mathrm{H}$ & $\mathrm{H}$ & Et & OEt \\
\hline
\end{tabular}

${ }^{\mathrm{a}}$ Condensation of isatin with cyclohexanone.

b 2 n, 2 diastereoisomers (ratio $1: 1), 20\left(170-171^{\circ} \mathrm{C}\right) ; \mathbf{2 p}\left(116-169^{\circ} \mathrm{C}\right)$. 
reaction occurred, vide infra. It was also found that maintaining the reaction at temperatures below zero $\left(\approx-15^{\circ} \mathrm{C}\right)$ inhibited the reaction, but the reaction recommenced on warming. Temperatures above those of room temperature were not investigated as it was known that 2-oxindole acetic acid derivatives can be reduced to indoline ethanols when refluxed with borane in THF. ${ }^{31}$ Indolines have also been obtained by the reaction of the $\mathrm{BH}_{3} \cdot \mathrm{NMe}_{3}$ complex with indoles under acidic conditions via the $3-H$-indolium ion. ${ }^{36}$

A closer investigation of the effect of reducing the reaction temperature revealed the formation of an intermediate during the reduction of $\mathbf{2 a}$. This intermediate was consumed when the reaction was allowed to warm to room temperature. The intermediate (5a), Equation 2, was subsequently isolated in $21 \%$ yield, along with $72 \%$ of the tryptophol $\mathbf{3 a}$, when the reaction was run using a deficiency of $\mathrm{BH}_{3}$.THF ( 2 mol equiv.).

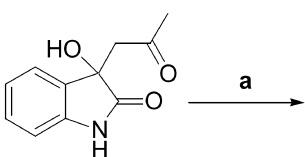

2a

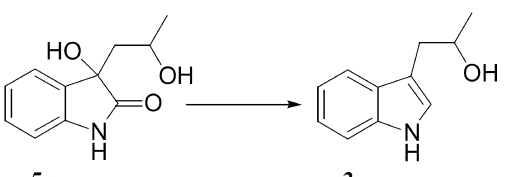

$5 a$ 3a
Equation 2. (a) 2 mol equiv. of $\mathrm{BH}_{3} \cdot \mathrm{THF}$

In an independent experiment, the reduction of $\mathbf{5 a}$ using an excess of $\mathrm{BH}_{3}$. THF yielded 3a quantitatively. Spectroscopic investigation of $\mathbf{5 a}$ by ${ }^{1} \mathrm{H}$ and ${ }^{13} \mathrm{C}$ NMR revealed it to be structurally related to the starting dioxindole $\mathbf{2 a}$. The following differences were observed: the ${ }^{1} \mathrm{H}$ methyl signal was now a doublet; the methylene hydrogens were now doublets of doublets; a new multiplet corresponding to one hydrogen at $3.97 \mathrm{ppm}(\mathrm{CH}$ methine) and a doublet at $4.44 \mathrm{ppm}(\mathrm{OH})$. The ${ }^{13} \mathrm{C}$ NMR revealed the absence of the keto-carbonyl and a new methine signal at $62 \mathrm{ppm}$. The adjacent methyl and methylene signals were shifted upfield by 7 and $5 \mathrm{ppm}$ ( $\delta 23.2$ and $\delta 44.5$ ) with respect to the substrate 2a, whereas the other ${ }^{13} \mathrm{C}$ signals were largely unaffected. The most notable changes in the infra-red spectrum of the product (5a) in comparison with the substrate (2a), were the disappearance of the keto-carbonyl stretching vibration $\left(1721 \mathrm{~cm}^{-1}\right)$ and a broadening of the absorption in the region $3400 \mathrm{~cm}^{-1}$. The spectroscopic data are entirely consistent with the reduction of the exocyclic keto-carbonyl group and no reduction of the dioxindole nucleus. Further, the ${ }^{1} \mathrm{H}$ and ${ }^{13} \mathrm{C}$ NMR data indicated that the product had a greater than $95 \%$ diastereomeric excess.

The successful synthesis of the tryptophol 3a prompted the investigation of the reduction of various isatin aldol condensation products (2b-t, Table 1). These substrates were prepared analogously to $\mathbf{2 a}$ or by using a modified methodology. Subsequent treatment with borane resulted in smooth reduction to give excellent yields of the respective tryptophol in all experiments; the results are summarised in Table 2. In a number of cases, it was found that 3 equiv. of $\mathrm{BH}_{3}$.THF were insufficient for the complete reduction of the substrate to the respective tryptophol. For example, the reduction of the cyclohexanone derivative $(\mathbf{2} \mathbf{j})^{37}$ required 4 equiv. of borane in THF. The reduction occurred stereoselectively yielding principally the trans isomer
(8:1). Preferential formation of the trans isomer is consistent with previously observed results of the reduction of $\alpha$-substituted cyclohexanones using $\mathrm{BH}_{3} \cdot \mathrm{THF}{ }^{11,38}$ The isomers were readily separated by column chromatography and individually characterized. The trans configuration of the major isomer was confirmed by comparison with data from the literature. ${ }^{13 \mathrm{~d}}$

The reduction of $\mathbf{2 m}$ also required 4 equiv. of $\mathrm{BH}_{3}$. THF in order to completely consume the substrate and to give the respective tryptophol $\mathbf{3 m}$ in $80 \%$ yield. When the same reaction was conducted using only 3 equiv. of $\mathrm{BH}_{3}$. THF, the tryptophol $\mathbf{3 m}$ was obtained in $63 \%$ yield along with a $25 \%$ yield of $\mathbf{5 m}$ (Equation 3). Compound $\mathbf{5 m}$ was unambiguously characterized as the intermediate diol by spectroscopic and elemental analyses. As in the case of $\mathbf{5 a}, \mathbf{5 m}$ was also obtained as essentially a single diastereoisomer.

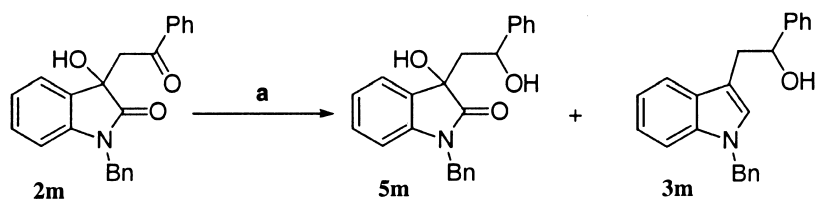

Equation 3. (a) 3 equiv. of $\mathrm{BH}_{3} \cdot \mathrm{THF}(\sim 1: 2.5$ mixture of $\mathbf{5 m} / \mathbf{3 m})$.

Having observed and characterised the formation of intermediate single diastereoisomer diols (5a and $\mathbf{5 m}$ ), it was of interest to investigate the origin of this diastereoselectivity. At first the possibility of a directed reduction of the keto-carbonyl group was considered. ${ }^{39,40}$ The alternative hypothesis being that reduction of the exocyclic ketocarbonyl group was not diastereoselective, thus generating an approximately one to one mixture of syn/anti diol diastereoisomers (5) which were subsequently reduced at different rates (kinetic resolution) to give the tryptophol 3a or $\mathbf{3 m}$ and, in essence, the single diastereomer $\mathbf{5 a}$ or $\mathbf{5 m}$ as a consequence of the deficiency of reducing agent. In order to investigate these hypotheses, the reduction of $\mathbf{2 a}$ was performed using $1 \mathrm{~mol}$ equiv. of $\mathrm{BH}_{3}$. THF. Spectroscopic analysis of the crude product by ${ }^{1} \mathrm{H}$ and ${ }^{13} \mathrm{C}$ NMR revealed the product to be a mixture of starting material (2a) and diastereomeric diols (5a), though it was not possible to determine a diastereomeric excess with any certainty. Further experiments to investigate the diastereoselective reduction of 2a using triacetoxyborohydride salts in THF were unsuccessful, no reaction occurred. ${ }^{41}$ Attempts to produce a mixture of the syn/anti 5a using sodium borohydride (in protic or aprotic solvents) were unsuccessful and resulted in complex mixtures of products. ${ }^{42}$

As the reduction of $\mathbf{2 a}$ using only 1 equiv. of $\mathrm{BH}_{3} \cdot \mathrm{THF}$ was found to give a mixture of the diols $\mathbf{5 a}$, but determination of the diastereomeric excess of $\mathbf{5 a}$ had proven to be difficult, and in order to further investigate the possibility of a diastereoselective reduction, the $N$-methyl derivative $\mathbf{2 b}$ was reduced with 1 equiv. of $\mathrm{BH}_{3}$.THF. After workup of the reaction in the manner described previously, or utilising an aqueous ammonium chloride workup, spectroscopic investigation of the crude reaction product revealed it to be a 2:1 mixture of the diastereomeric diols $(\mathbf{5 b})$ with no other product present $(93 \%$ yield). This mixture was readily 
Table 2. Tryptophol products obtained in this study

\begin{tabular}{rr}
\hline Product & Yield $(\%)$ \\
& $\mathrm{mp}\left({ }^{\circ} \mathrm{C}\right)$
\end{tabular}

3a<smiles>CC(O)Cc1c[nH]c2ccccc12</smiles>

3b<smiles>CC(O)CC1CN(C)C2CC=CC12</smiles>

3c<smiles>CC(O)CC1CC23CNC(C=C1I)C2C3</smiles>

3d<smiles>CC(O)CC1CC2C=CC([N+](=O)[O-])CC2C1</smiles>

$3 e$<smiles>CC(O)Cc1c[nH]c2cc(Br)cc-2c1Br</smiles>

3f<smiles>CC(O)CC1CNc2c(Br)cc(Br)cc21</smiles>

3g<smiles></smiles>

3h<smiles>OC(Cc1ccccc1)C1=Cc2c(Br)cc(Br)cc21</smiles>

3i<smiles>OC(Cc1cc2cc(Br)cc(Br)c2[nH]1)c1ccccc1</smiles>

3j<smiles>OC1CCCCC1c1c[nH]c2ccccc12</smiles>

3k<smiles>CC(C)(C)C(O)Cc1c[nH]c2ccccc12</smiles>

31<smiles>CN1CC2CC=CC2C1CC(C)(O)C(C)(C)C</smiles>

$3 m$<smiles>OC(CC1CN(Br)C2CC=CC=C12)c1ccccc1</smiles>

3n<smiles>CC(O)C(O)Cc1c[nH]c2c1CCC2</smiles>

90

$53-54$

89 ,

74-75

86,

$93-95$

66, 155-157

90 ,

92 ,

85 ,

oil

88 ,

151-152

90 ,

120-121

80 (trans), $157-160^{\mathrm{b}}$

82, 121-122

80 , 49-50

80 ,

83-85,

$\mathrm{oil}^{\mathrm{c}}$
Table 2 (continued)

\begin{tabular}{lc}
\hline Product & Yield (\%), \\
&
\end{tabular}

$\mathrm{mp}\left({ }^{\circ} \mathrm{C}\right)$

$3 \mathbf{q}$

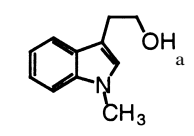

87

oil

$3 \mathbf{r}$

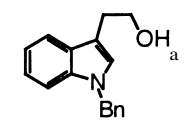

90 ,

oil

$3 s$

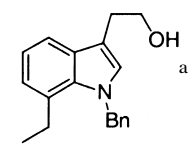

$3 \mathbf{t}$

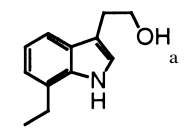

78

$47-48$

All compounds gave satisfactory analytical and/or spectroscopic data. A typical experimental procedure: dioxindole $(1 \mathrm{mmol})$ was solubilised in anhydrous THF $(5 \mathrm{ml})$. To this was added a solution of $\mathrm{BH}_{3}$.THF $(1 \mathrm{M}$, $3 \mathrm{ml}$ ) under a nitrogen atmosphere. The reaction mixture was stirred at room temperature until TLC indicated complete consumption of the substrate (typically a few hours). The reaction was subsequently quenched with aqueous $\mathrm{HCl}(2 \mathrm{~N})$ and neutralised with aqueous $\mathrm{NaOH}(2 \mathrm{~N})$. Dilution of the reaction mixture with water and extraction with ethyl acetate gave the crude product. Pure tryptophols were obtained by filtration through a short column of silica with $\mathrm{CH}_{2} \mathrm{Cl}_{2}$.

${ }^{\text {a }}$ Four mole equivalents of $\mathrm{BH}_{3}$.THF were required for complete consumption of the substrate.

${ }^{\mathrm{b}}$ trans/cis, $8: 1 ;$ cis $110-112^{\circ} \mathrm{C}$

c The same 4:1 mixture of diol indole diastereoisomers was obtained in all three reactions irrespective of the starting material $[2 \mathbf{n}, 2$ diastereoisomers $\left.(1: 1), 20\left(170-171^{\circ} \mathrm{C}\right) ; \mathbf{2 p}\left(116-119^{\circ} \mathrm{C}\right)\right]$. The relative stereochemistry of the major diastereoisomer has not been unambiguously determined.

reduced to the tryptophol $\mathbf{3 b}$ in $94 \%$ yield upon treatment with 3 equiv. of borane, Equation 4.

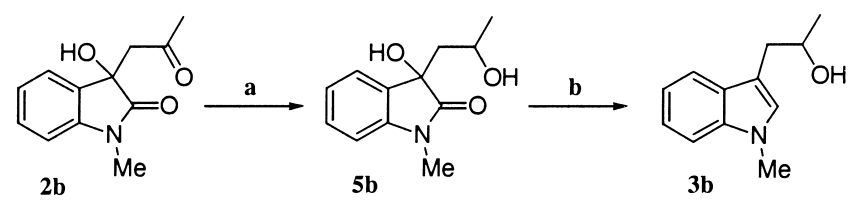

Equation 4. (a) $1 \mathrm{~mol} \mathrm{BH} \cdot$.THF; (b) $3 \mathrm{~mol} \mathrm{BH} 3$.THF.

In a similar manner, the reduction of $\mathbf{2} \mathbf{m}$ was conducted using $1 \mathrm{~mol}$ equiv. of $\mathrm{BH}_{3} \cdot \mathrm{THF}$. This experiment furnished a 3:1 mixture of the diastereomeric diols (5m) in 97\% yield. Comparison of the spectral data for the single diastereoisomer, obtained when $3 \mathrm{~mol}$ of $\mathrm{BH}_{3} \cdot \mathrm{THF}$ were used (Equation 3), with that of the mixture of the two diastereoisomers, revealed it to have the same structure as the major diastereoisomer. Therefore, the origin of the single diol diastereoisomer in the preceding experiments, where a deficiency of borane was utilised during the synthesis of the respective tryptophols, lies in a mildly diastereoselective reduction of the keto-carbonyl group and not in a kinetic resolution of the diols (although differences in the rates of reduction of the diols may have a minimal role).

Compound 2n was first prepared by condensation of 3-hydroxy-2-butanone with isatin in methanol at room 
temperature in the presence of a catalytic quantity of diethylamine yielding a 1:1 mixture of the diastereoisomers 20 and 2p. On workup it was found that one of the diastereomers (2o, the isomer with the higher melting point) was reasonably insoluble in ethyl acetate, thus separation of the diastereoisomers could be achieved by fractional crystallisation. Subsequently, the synthesis of $2 \mathbf{n}$ was performed in ethyl acetate under otherwise equivalent conditions, but in this case the ethyl acetate insoluble isomer $\mathbf{2 0}$ precipitated during the reaction. The isomer $\mathbf{2 p}$ was obtained as a crystalline solid by the slow evaporation of the ethyl acetate solution enriched with the soluble isomer. The reduction of compounds $\mathbf{2 n}-\mathbf{p}$ was realized using 4 equiv. of $\mathrm{BH}_{3} \cdot \mathrm{THF}$ and in each case it was found that the reactions yielded the same mixture $(4: 1)$ of diastereomeric tryptophol diols (3n).These diastereoisomeric diols have been recently isolated from a Streptomyces broth. ${ }^{43}$

In addition, tryptophols without $\alpha$ - or $\beta$-substituents can be prepared by the reduction of (3-hydroxy-2-oxindol-3-yl)acetates. ${ }^{8 a}$ Examples of these compounds have been prepared by the Reformatsky reaction. ${ }^{8 \mathrm{a}, 44}$ As an alternative method, the reaction of $N$-alkylisatin derivatives and malonic acid (1.1 equiv.) in a 1:3 mixture of pyridine and ethanol was conducted under reflux for $20 \mathrm{~h}$ resulting in the obtention of (3-hydroxy-2-oxindol-3-yl)-acetic acids which were isolated by evaporation of the solvent and addition of dilute aqueous $\mathrm{HCl}$ followed by filtration, washing with water, and air drying (Equation 5). The intermediate acids were of sufficiently good quality that they could be used in the next step without further purification. Esterification was performed by the dropwise addition of $\mathrm{SOCl}_{2}$ to a methanolic solution of the acid (Equation 5). The resulting esters $(\mathbf{2 q}-\mathbf{s})$ were subsequently purified by filtration through a short column of silica. Esters $\mathbf{2 q}-\mathbf{s}$ were reduced with 4 equiv. of $\mathrm{BH}_{3}$.THF to give excellent yields of the respective tryptophols (Table 2, 3q-s). However, this procedure was found to be incompatabile with isatin derivatives that were not $N$-alkylated. These substrates yielded the respective quinolone derivatives upon esterification via ring opening and ring closure. Therefore, an alternative procedure employing the potassium salt of the mono-ethyl malonyl ester with 7-ethylisatin in a mixture of pyridine, acetic acid and ethanol under reflux was investigated. This modified Knovenagel reaction gave the $\beta$-hydroxyester (2t) in good yield. Ester $\mathbf{2 t}$ was subsequently reduced with $\mathrm{BH}_{3}$. THF to give the corresponding tryptophol after acidic workup (Equation 5). The use of an aqueous ammonium chloride workup resulted in the isolation of substantial quantities $(\approx 20 \%)$ of the ethyl ether of the respective tryptophol.

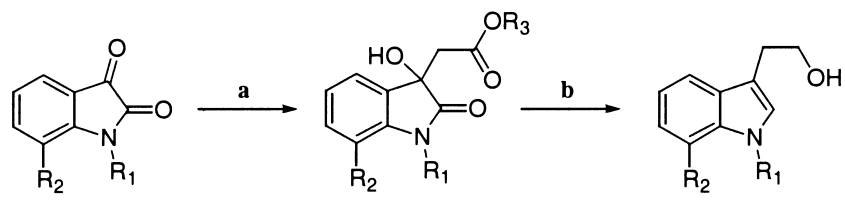

Equation 5. For $\mathrm{R}_{1}=\mathrm{Me}$ or $\mathrm{Bn} ; \mathrm{R}_{2}=\mathrm{H}$ a (1) $\mathrm{CH}_{2}\left(\mathrm{CO}_{2} \mathrm{H}\right)$, pyridine, $\mathrm{EtOH}$ (1:3 v/v), $\triangle$, (2) $\mathrm{SOCl}_{2}, \mathrm{MeOH}\left(\mathrm{R}_{3}=\mathrm{Me}\right)$; (b) $\mathrm{BH}_{3}$. THF; for $\mathrm{R}_{1}=\mathrm{H} ; \mathrm{R}_{2}=\mathrm{Et}$. (a) $\mathrm{EtO}_{2} \mathrm{CCH}_{2} \mathrm{CO}_{2} \mathrm{~K}$, pyridine, AcOH, EtOH $(5: 2: 15 \mathrm{v} / \mathrm{v} / \mathrm{v}), \triangle ; \mathrm{R}_{3}=\mathrm{Et}$; (b) $\mathrm{BH}_{3} \cdot \mathrm{THF}$.

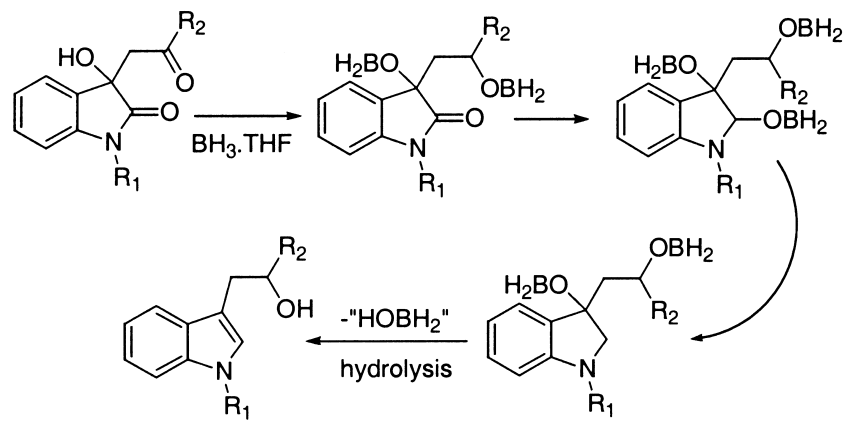

Scheme 1. Simplified reaction mechanism for the obtention of tryptophols by the $\mathrm{BH}_{3} \cdot \mathrm{THF}$ reduction of isatin aldol adducts.

The foregoing results are consistent with a mechanism that involves diastereoselective reduction of the ketone to the secondary alcohol due to the presence of the $\beta$-asymmetric tertiary alcohol. The diastereoselective reduction can be envisaged to occur either by external or internal hydride delivery. ${ }^{45}$ The amide carbonyl is subsequently reduced to the amine in a two step process via a carbinolamine borate ester. ${ }^{46}$ Subsequent elimination of the leaving group bonded to $\mathrm{C}-3$ with concomitant deprotonation of $\mathrm{C}-2$ would yield the tryptophol (Scheme 1).

\section{Conclusion}

In conclusion, we have found that the use of $\mathrm{BH}_{3} \cdot \mathrm{THF}$ solutions for the reduction of isatin aldol or Knovenagel products $(\mathbf{2 a}-\mathbf{t})$ to be not only a very convenient method, but also to be a readily reproducible and high yielding method for the synthesis of a diverse range of tryptophols $(3 \mathbf{a}-\mathbf{t})$. We have also found that the reduction of compounds 2 proceeds via diol intermediates (5) that may be obtained with limited stereoselectivity when a $1 \mathrm{~mol}$ equiv. of borane is used. However, reduction of $\mathbf{2}$, using an insufficient quantity of borane for complete reduction to give 3, does allow isolation, in low yields, of what was identified as being the major diol diastereoisomer of $\mathbf{5}$ along with the corresponding tryptophol $\mathbf{3}$ as the principle product.

\section{Experimental}

General. ${ }^{1} \mathrm{H}$ and ${ }^{13} \mathrm{C}$ NMR spectra were recorded using 300 and $200 \mathrm{MHz}\left({ }^{1} \mathrm{H}\right)$ Bruker spectrometers and are referenced to $\mathrm{CHCl}_{3}$. Coupling constants are quoted in $\mathrm{Hz} .{ }^{1} \mathrm{H}$ and ${ }^{13} \mathrm{C}$ NMR assignments, where given, were based upon 2D experiments (COSY, HMQC, and HMBC) or by comparison with related structures. Primary (p), secondary (s), tertiary (t) and quaternary (q) assignments in ${ }^{13} \mathrm{C}$ spectra were based upon analysis of PENDANT spectra. Mass spectra were recorded using a Hewlett-Packard GC-MS or by direct insertion using a VG Autospec. Infra-red spectra were recorded using a Perkin-Elmer 1600 FT-IR as either $\mathrm{KBr}$ or $\mathrm{KCl}$ discs. Melting points were recorded using a Meltemp II capillary melting point apparatus and are reported as uncorrected values. THF was dried by refluxing with a $\mathrm{Na} / \mathrm{K}$ alloy and benzophenone. $\mathrm{BF}_{3} \cdot \mathrm{Et}_{2} \mathrm{O}$, purified and redistilled, (Aldrich) was used as received. Isatin was 
purchased from Merck and $\mathrm{NaBH}_{4}$ from Grupo Química and Merck. The isatin derivatives were prepared using literature procedures. ${ }^{47}$

\subsection{General method for the synthesis of the acetone aldol adducts}

Isatin $(10 \mathrm{mmol})$ was solubilised/suspended in acetone $(50 \mathrm{ml})$ to which was added a few drops of $\mathrm{Et}_{2} \mathrm{NH}$. The reaction mixture was left stirring at room temperature until complete consumption of the respective isatin had occurred. The excess acetone was removed by rotary evaporation under reduced pressure. The crude product was extracted with hot ethyl acetate, filtered and the ethyl acetate solution evaporated to yield the respective product which was used without further purification.

Alternatively, $\mathrm{K}_{2} \mathrm{CO}_{3}(10 \mathrm{~mol} \%)$ was used as the basic catalyst. The reactions were filtered through a pad of diatomaceous earth and evaporated under reduced pressure. The crude product was used without further purification.

4.1.1. 3-Hydroxy-3-(2-oxopropyl)-2-oxindole (2a). Yield $85 \%$; mp $166-168^{\circ} \mathrm{C}$; lit. $^{34} 166-167^{\circ} \mathrm{C}$.

4.1.2. $N$-Methyl-3-hydroxy-3-(2-oxopropyl)-2-oxindole (2b). Yield $70 \%$; mp $146-148^{\circ} \mathrm{C}$; lit. ${ }^{34} 145^{\circ} \mathrm{C}$.

4.1.3. 5-Iodo-3-hydroxy-3-(2-oxopropyl)-2-oxindole (2c). Yield 80\%; mp $232-234^{\circ} \mathrm{C}$; lit. ${ }^{48} 233-235^{\circ} \mathrm{C}$.

4.1.4. 5-Nitro-3-hydroxy-3-(2-oxopropyl)-2-oxindole (2d). Yield 55\%; mp $237-239^{\circ} \mathrm{C}$; lit. $^{48} 239-240^{\circ} \mathrm{C}$.

4.1.5. 4,6-Dibromo-3-hydroxy-3-(2-oxopropyl)-2-oxindole (2e). Yield $77 \%$ (recryst. $\mathrm{CHCl}_{3}$ ); mp $198-202^{\circ} \mathrm{C}$ (decomp.), ${ }^{47 a}$ lit. $^{49} 190-195^{\circ} \mathrm{C}$.

4.1.6. 5,7-Dibromo-3-hydroxy-3-(2-oxopropyl)-2-oxindole (2f). Yield $83 \%$; mp $173-175^{\circ} \mathrm{C}$. $^{47 \mathrm{a}}$

\subsection{Acetophenone and pinacolone condensation products. General condensation procedure}

Isatin derivative $(10 \mathrm{mmol})$ was solubilised/suspended in $\mathrm{MeOH}(30 \mathrm{ml})$. To this was added 2 equiv. of methyl ketone (acetophenone or pinacolone) followed by a few drops of $\mathrm{Et}_{2} \mathrm{NH}$. The reaction mixture was stirred at room temperature (or refluxed) until complete consumption of the starting material as judged by TLC. The reaction mixtures were evaporated under reduced pressure to yield the crude products which were subsequently recrystallised.

4.2.1. 3-Hydroxy-3-(2-phenyl-2-oxoethyl)-2-oxindole (2g). Recrystallised from EtOAc/hexane. Yield 80\%; mp $175-177^{\circ} \mathrm{C}$; lit. $^{50} 173-175^{\circ} \mathrm{C}$.

4.2.2. 5,7-Dibromo-3-hydroxy-3-(2-phenyl-2-oxoethyl)2-oxindole (2i). Recrystallised from $\mathrm{CH}_{2} \mathrm{Cl}_{2} /$ hexane. Yield $89 \%$; $\mathrm{mp} 162-165^{\circ} \mathrm{C}$. IR $\left(\mathrm{cm}^{-1}\right)$ : 3330, 3192, 1730 , 1708, 1678, 1619, 1462, 1349, 1218, 1158, 1082, 996, 859, 752, 691. Mass, $m / z(\%): 427\left(\mathrm{M}^{+\cdot}, \mathrm{C}_{16} \mathrm{H}_{11}^{81} \mathrm{Br}_{2} \mathrm{NO}_{3}, 3\right), 425$ $\left(\mathrm{M}^{+\cdot \mathrm{C}}, \mathrm{C}_{16} \mathrm{H}_{11}^{79}, 81 \mathrm{Br}_{2} \mathrm{NO}_{3}, 8\right), 423\left(\mathrm{M}^{+\cdot}, \mathrm{C}_{16} \mathrm{H}_{11}^{79} \mathrm{Br}_{2} \mathrm{NO}_{3}, 4\right)$,
380 (59), 320 (13), 304 (10), 277 (15), 249 (5), 170 (7), 120 (10), 105 (100), 77 (76). ${ }^{1} \mathrm{H}$ NMR (300 MHz, $\mathrm{CDCl}_{3}$, DMSO-d $\left.{ }_{6}\right): \delta 2.95[1 \mathrm{H}, \mathrm{d}, \mathrm{H}-8, J=18.0 \mathrm{~Hz}], 3.30[1 \mathrm{H}, \mathrm{d}$, $\left.\mathrm{H}-8^{\prime}, J=18.0 \mathrm{~Hz}\right], 4.76[1 \mathrm{H}, \mathrm{s}, \mathrm{OH}], 6.66[1 \mathrm{H}, \mathrm{d}, \mathrm{H}-6$, $J=1.8 \mathrm{~Hz}], 6.69$ [2H, t, H-12, $J=7.5 \mathrm{~Hz}], 6.71[1 \mathrm{H}, \mathrm{d}, \mathrm{H}-4$, $J=1.8 \mathrm{~Hz}], 6.82[1 \mathrm{H}, \mathrm{t}, \mathrm{H}-13, J=7.5 \mathrm{~Hz}], 7.11[2 \mathrm{H}, \mathrm{d}, \mathrm{H}-11$, $J=7.5 \mathrm{~Hz}], 9.90[1 \mathrm{H}$, bs, $\mathrm{NH}] .{ }^{13} \mathrm{C}$ NMR $(75.5 \mathrm{MHz}$, $\mathrm{CDCl}_{3}, \mathrm{DMSO}_{6}$ ): $\delta 44.7$ [s, C-8], 72.6 [q, C-3], 101.4 [q, C-7], 112.2 [q, C-5], 124.3 [t, C-6], 126.5* [t, C-11], 127.2* [t, C-12], 132.1 [t, C-13], 132.1 [t, C-4], 134.0 [q, C-3a], 134.4 [q, C-10], 140.6 [q, C-7a], 176.5 [q, C-2], 194.80 [q, C-9]. The assignments for the signals marked $*$ may be interchanged.

4.2.3. 4,6-Dibromo-3-hydroxy-3-(2-phenyl-2-oxoethyl)2-oxindole (2h). Recrystallised from $\mathrm{CH}_{2} \mathrm{Cl}_{2} /$ hexane. Yield 80\%; mp 195-200 ${ }^{\circ} \mathrm{C}$. IR $\left(\mathrm{cm}^{-1}\right): 3382,3170,1715$, 1683, 1609, 1576, 1355, 1216, 1066, 839, 687. Mass, $m / z \quad(\%): 427 \quad\left(\mathrm{M}^{+\cdot}, \mathrm{C}_{16} \mathrm{H}_{11}^{81} \mathrm{Br}_{2} \mathrm{NO}_{3}, \quad 9\right), 425 \quad\left(\mathrm{M}^{+*}\right.$, $\left.\mathrm{C}_{16} \mathrm{H}_{11}^{79,81} \mathrm{Br}_{2} \mathrm{NO}_{3}, 21\right), 423\left(\mathrm{M}^{+\cdot}, \mathrm{C}_{16} \mathrm{H}_{11}^{79} \mathrm{Br}_{2} \mathrm{NO}_{3}, 10\right), 407$ (4), 380 (6), 328 (6), 316 (13), 306 (16), 277 (9), 120 (70), 105 (100), 77 (50). ${ }^{1} \mathrm{H}$ NMR (300 MHz, $\left.\mathrm{CDCl}_{3}, \mathrm{DMSO}_{6}\right)$ : $\delta 3.76[1 \mathrm{H}, \mathrm{d}, \mathrm{H}-8, J=18.0 \mathrm{~Hz}], 4.56\left[1 \mathrm{H}, \mathrm{d}, \mathrm{H}-8^{\prime}, J=\right.$ $18.0 \mathrm{~Hz}], 6.20[1 \mathrm{H}, \mathrm{bs}, \mathrm{OH}], 7.05[1 \mathrm{H}, \mathrm{d}, \mathrm{H}-7, J=1.6 \mathrm{~Hz}]$, $7.15[1 \mathrm{H}, \mathrm{d}, \mathrm{H}-5, J=1.6 \mathrm{~Hz}], 7.45[1 \mathrm{H}, \mathrm{t}, \mathrm{H}-12, J=7-8 \mathrm{~Hz}]$, $7.58[1 \mathrm{H}, \mathrm{t}, \mathrm{H}-13, J=7-8 \mathrm{~Hz}], 7.89[1 \mathrm{H}, \mathrm{d}, \mathrm{H}-11, J=$ $8.0 \mathrm{~Hz}], 10.45[1 \mathrm{H}, \mathrm{bs}, \mathrm{NH}] .{ }^{13} \mathrm{C} \mathrm{NMR}\left(75.5 \mathrm{MHz}, \mathrm{CDCl}_{3}\right.$, DMSO-d $\left.{ }_{6}\right): \delta 43.2$ [s, C-8], 73.6 [q, C-3], 111.6 [t, C-7], 117.9 [q, C-6], 122.0 [q, C-4], 126.4 [t, C-5], 126.8* [t, C-11], 127.3 [q, C-3a], 127.5* [t, C-12], 132.4 [t, C-13], 134.7 [C-10], 145.2 [C-7a], 177.0 [C-2], 195.4 [C-9]. The assignments for the signals marked $*$ may be interchanged.

4.2.4. $N$-Benzyl-3-hydroxy-3-(2-phenyl-2-oxoethyl)-2oxindole $^{51}(\mathbf{2 m})$. The title compound was crystallised from the reaction medium and isolated by filtration and washed with small portions of cold $\mathrm{MeOH}$. More product was obtained by concentration of the filtrate. Yield 82\%; mp $192-196^{\circ} \mathrm{C}$. IR $\left(\mathrm{cm}^{-1}\right)$ : 3323, 3075, 3030, 2897, 1697, 1682, 1618, 1496, 1389, 1348, 1216, 1180, 1070, 1008, 767, 733, 685, 643. Mass, $m / z(\%): 357\left(\mathrm{M}^{+*}, 17\right), 312(4), 238$ (8), 237 (13), 209 (6), 180 (10), 146 (35), 120 (10), 105 (81), 91 (100), 77 (56), 65 (25), 51 (19). ${ }^{1} \mathrm{H}$ NMR (200 MHz, $\mathrm{CDCl}_{3}, \mathrm{DMSO}_{6}$ ): $\delta 3.84[1 \mathrm{H}, \mathrm{d}, \mathrm{H}-8, J=17.4 \mathrm{~Hz}], 4.04$ [1H, d, H-8 $\left.{ }^{\prime}, J=17.4 \mathrm{~Hz}\right], 4.95$ [2H, s, H-14, $\mathrm{CH}_{2}$ benzyl], $6.18[1 \mathrm{H}, \mathrm{s}, \mathrm{OH}], 6.69[1 \mathrm{H}, \mathrm{d}, \mathrm{H}-7, J=7.6 \mathrm{~Hz}], 6.94[1 \mathrm{H}, \mathrm{t}$, $\mathrm{H}-5, J=7.6 \mathrm{~Hz}], 7.15[1 \mathrm{H}, \mathrm{td}, \mathrm{H}-6, J=1.2,7.6 \mathrm{~Hz}], 7.2-7.6$ $[9 \mathrm{H}, \mathrm{m}], 7.88[2 \mathrm{H}, \mathrm{d}, \mathrm{H}-11, J=7.8 \mathrm{~Hz}] .{ }^{13} \mathrm{C}$ NMR $(50 \mathrm{MHz}$, $\mathrm{CDCl}_{3}, \mathrm{DMSO}_{6}$ ): $\delta 45.5$ [s,C-8], 43.1 [s, C-14], 72.7 [q, C-3], 108.6 [t, C-7], 121.8 [t, C-5], 122.7 [t, C-6], 126.7 [t, C-16], 126.8 [t, C-17], 127.4* [t, C-11], 127.9* [t, C-12], 128.0 [t, C-18], 128.7 [t, C-4], 130.3 [q, C-3a], 132.8 [t, C-13], 135.4 ${ }^{\#}$ [q, C-10], 135.7 ${ }^{\#}$ [q, C-15], 143.0 [q, C-7a], 176.6 [q, C-2], 195.8 [q, C-9]. The assignments for the signals marked $*$ or \# may be interchanged.

4.2.5. 3-Hydroxy-3-(3,3'-dimethyl-2-oxobutyl)-2-oxindole $^{52}(\mathbf{2 k})$. The title compound was prepared by refluxing the reagents in $\mathrm{MeOH}$ and purified by filtration through a column of silica eluting with $\mathrm{CH}_{2} \mathrm{Cl}_{2}$. Yield 53\%; mp $158-$ $161^{\circ} \mathrm{C}$. IR $\left(\mathrm{cm}^{-1}\right): 3362,3272,2966,1735,1698,1627$, 1474, 1340, 1185, 1045, 752. Mass, $m / z(\%): 247\left(\mathrm{M}^{+*}, 16\right)$, 202 (6), 190 (7), 162 (46), 148 (100), 147 (18), 120 (27), 
119 (22), 92 (23), 57 (57). ${ }^{1} \mathrm{H}$ NMR (300 MHz, $\mathrm{CDCl}_{3}$, DMSO-d 6 ): $\delta 1.05\left[9 \mathrm{H}, \mathrm{s}, \mathrm{H}-11, \mathrm{CH}_{3}, t\right.$-butyl], $3.19[1 \mathrm{H}, \mathrm{d}$, $\mathrm{H}-8, J=17.6 \mathrm{~Hz}], 3.44\left[1 \mathrm{H}, \mathrm{d}, \mathrm{H}-8^{\prime}, J=17.6 \mathrm{~Hz}\right], 5.68[1 \mathrm{H}$, bs, OH], $6.87[1 \mathrm{H}, \mathrm{d}, \mathrm{H}-7, J=7.7 \mathrm{~Hz}], 6.94[1 \mathrm{H}, \mathrm{td}, \mathrm{H} 5$, $J=0.9,7.3 \mathrm{~Hz}], 7.18[1 \mathrm{H}, \mathrm{td}, \mathrm{H}-6, J=1.2,7.7 \mathrm{~Hz}], 7.24[1 \mathrm{H}$, d, H-4, J=7.3 Hz], $9.71[1 \mathrm{H}, \mathrm{bs}, \mathrm{NH}] .{ }^{13} \mathrm{C}$ NMR $(75.5 \mathrm{MHz}$, $\mathrm{CDCl}_{3}, \mathrm{DMSO}_{\mathrm{d}}$ ): $\delta 25.6$ [p, C-11], 43.5 [s, C-8], 43.8 [q, C-10], 73.6 [q, C-3], 110.0 [t, C-7], 121.6 [t, C-5], 123.1 [t, C-6], 129.1 [t, C-4], 130.7 [q, C-3a], 142.0 [q, C-7a], 178.6 [q, C-2], 213.1 [q, C-9].

4.2.6. $N$-Methyl-3-hydroxy-3-(3,3'-dimethyl-2-oxobutyl)2-oxindole (2l). Prepared as for compound 2k. Yield: 50\%; mp $150-152^{\circ} \mathrm{C}$. IR $\left(\mathrm{cm}^{-1}\right): 3350,3168,2970,1731,1698$, 1614, 1473, 1379, 1349, 1112, 1090, 1061, 1000, 805, 764, 748. Mass, $\mathrm{m} / \mathrm{z}$ (\%): $261\left(\mathrm{M}^{+*}, 22\right), 239$ (6), 217 (4), 176 (32), 162 (100), 160 (27), 134 (10), 130 (9), 104 (14), 91 (31), 77 (27), 57 (56). ${ }^{1} \mathrm{H}$ NMR (200 MHz, CDCl 3 , DMSO$\left.\mathrm{d}_{6}\right): \delta 1.08\left[9 \mathrm{H}, \mathrm{s}, \mathrm{H}-11, \mathrm{CH}_{3}, t\right.$-butyl], $3.03[1 \mathrm{H}, \mathrm{d}, \mathrm{H}-8$, $J=17.5 \mathrm{~Hz}], 3.21\left[3 \mathrm{H}, \mathrm{s}, \mathrm{NCH}_{3}\right], 3.34\left[1 \mathrm{H}, \mathrm{d}, \mathrm{H}-8^{\prime}, J=\right.$ $17.5 \mathrm{~Hz}], 4.69[1 \mathrm{H}, \mathrm{bs}, \mathrm{OH}], 6.84[1 \mathrm{H}, \mathrm{d}, \mathrm{H}-7, J=8.0 \mathrm{~Hz}]$, $7.04[1 \mathrm{H}, \mathrm{td}, \mathrm{H}-5, J=0.8,7.5 \mathrm{~Hz}], 7.27-7.34[2 \mathrm{H}, \mathrm{m}, \mathrm{H}-4$ and H-6]. ${ }^{13} \mathrm{C} \mathrm{NMR}\left(50 \mathrm{MHz}, \mathrm{CDCl}_{3}, \mathrm{DMSO}-\mathrm{d}_{6}\right): \delta 26.1[\mathrm{p}$, C-11], 26.4 [p, C-12, $\mathrm{CH}_{3} \mathrm{~N}$ ], 43.0 [s, C-8], 44.8 [q, C-10], 74.6 [q, C-3], 108.7 [t, C-7], 123.1 [t, C-5], 123.7 [t, C-6], 130.1 [t, C-4], 130.2 [q, C-3a], 143.9 [q, C-7a], 176.5 [q, C-2], 215.3 [q, C-9].

\subsection{Condensation with cyclohexanone}

4.3.1. 3-Hydroxy-3-(2-oxocyclohexyl)-2-oxindole (2j). Isatin $(10 \mathrm{mmol})$ was suspended in EtOAc $(20 \mathrm{ml})$ to which was added cyclohexanone $(30 \mathrm{mmol})$ and a few drops of $\mathrm{Et}_{2} \mathrm{NH}$. The reaction mixture was left stirring at room temperature until complete consumption of the isatin had occurred $(24 \mathrm{~h})$. The product partially precipitated during the reaction. The precipitate was removed by filtration and the filtrate concentrated under reduced pressure. The combined solids were recrystallised from acetone/hexane to give a $4: 1$ mixture of diastereoisomers in $72 \%$ yield, $\mathrm{mp}$ $167-175^{\circ} \mathrm{C}$; lit. ${ }^{53} 198-199^{\circ} \mathrm{C}$. A similar procedure using $\mathrm{MeOH}$ as the solvent gave a 1.6:1 mixture of diastereoisomers in $64 \%$ yield. IR $\left(\mathrm{cm}^{-1}\right)$ : 3339, 3293, 3203, 3169, 3027, 2944, 2868, 1723, 1688, 1619, 1470, 1381, 1215, 1047, 757. Mass, $m / z(\%): 245\left(\mathrm{M}^{+*}, 39\right), 227$ (8), $172(7)$, 162 (10), 148 (90), 147 (15), 120 (29), 119 (22), 98 (100), 92 (22), 70 (25). ${ }^{1} \mathrm{H}$ NMR (300 MHz, $\mathrm{CDCl}_{3}$, DMSO-d $\left.{ }_{6}\right): \delta$ $1.4-2.6[8 \mathrm{H}, \mathrm{m}], 3.14[1 \mathrm{H}, \mathrm{dd}, \mathrm{H}-8, J=5.3,12.9 \mathrm{~Hz}], 5.80$ [1H, s, OH], $6.88[2 \mathrm{H}, \mathrm{m}, \mathrm{H}-7$ and $\mathrm{H}-5], 7.17[1 \mathrm{H}, \mathrm{t}, \mathrm{H}-6$, $J=7.4 \mathrm{~Hz}], 7.25[1 \mathrm{H}, \mathrm{d}, \mathrm{H}-4, J=7.4 \mathrm{~Hz}], 10.07$ and 10.10 [1H, s, NH diastereoisomers]. ${ }^{13} \mathrm{C}$ NMR $\left(75.5 \mathrm{MHz} \mathrm{CDCl}_{3}\right.$, DMSO- $\mathrm{d}_{6}$ ): $\delta$ Major diastereoisomer 23.8 [s, C-12], 25.8 [s, C-11], 26.0 [s, C-10], 56.4 [t, C-8], 73.8 [q, C-3], 108.9 [t, C-7], 120.3 [t, C-5], 123.7 [t, C-6], 127.9 [t, C-4], 129.5 [q, C-3a], 142.3 [q, C-7a], 178.3 [q, C-2], 208.7 [q, C-9].

4.4. Condensation of 3-hydroxybutan-2-one. Synthesis and isolation of the diastereoisomers of 3-hydroxy-3-(3hydroxy-2-oxobutyl)-2-oxindole (2n-the mixture, 20 and $2 \mathrm{p}$ - the individual diastereoisomers)

Isatin (10 mmol) was solubilised/suspended in $\mathrm{MeOH}$ $(20 \mathrm{ml})$. To this was added 3-hydroxybutan-2-one
(20 mmol) and a few drops of $\mathrm{Et}_{2} \mathrm{NH}$. The reaction mixture was stirred at room temperature during $24 \mathrm{~h}$. The complete consumption of the isatin was verified by TLC. The reaction mixture was evaporated under reduced pressure and the crude product was filtered through a short column of silica using $\mathrm{CH}_{2} \mathrm{Cl}_{2} /$ EtOAc (1:4 v/v) as eluent. Evaporation of the solvent gave the diastereomeric mixture (2n) as a colourless solid $(73 \%$ yield). The initial ratio of the diastereoisomers (3:1) was determined from analysis of the ${ }^{1} \mathrm{H}$ NMR spectrum. The $\mathrm{H}-11\left(\mathrm{CH}_{3}\right)$ and the $\mathrm{H}-9$ $(\mathrm{CH}-\mathrm{OH})$ signals were sufficiently resolved permitting comparison of the integrated peak areas.

The diastereomeric mixture was solubilised in hot EtOAc, on cooling a product crystallized. The product was removed by filtration and washed with small portions of cold EtOAc. This product, compound 2o, was determined to be the diastereoisomer of higher melting point ( $40 \%$ yield). The filtrate was allowed to slowly evaporate. During this process, a colourless product crystallized. The solid was separated by filtration and determined to be the diastereoisomer (2p) of lower melting point (14\% yield).

Alternatively, the reaction may be performed in EtOAc as solvent. This results in the precipitation of a colourless product in $68 \%$ yield (a further $20-25 \%$ of product can be obtained from the filtrate) that was found to be a 3:1 mixture of diastereoisomers. Recrystallisation from EtOAc gave the diastereoisomer of higher melting point in $48 \%$ yield.

4.4.1. Characterization data for the less soluble diastereoisomer (2o). Yield: $48 \%$; mp $170-172^{\circ} \mathrm{C}$; lit. ${ }^{23} 172-180^{\circ} \mathrm{C}$. IR $\left(\mathrm{cm}^{-1}\right)$ : 3504, 3331, 3185, 2987, 1731, 1703, 1620, 1477, 1399, 1334, 1307, 1216, 1187, 1018, 775, 756. Mass,

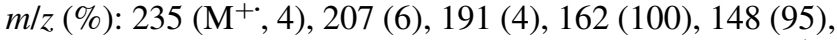
147 (9), 146 (34), 120 (23), 119 (14), 92 (20), 65 (14). ${ }^{1} \mathrm{H}$ NMR (300 MHz, $\mathrm{CDCl}_{3}$, DMSO-d $\left.{ }_{6}\right): \delta 1.23[3 \mathrm{H}, \mathrm{d}, \mathrm{H}-11$, $J=6.9 \mathrm{~Hz}], 3.17$ [1H, d, H-8, $J=17.1 \mathrm{~Hz}], 3.49$ [1H, d, H-8', $J=17.1 \mathrm{~Hz}], 4.08[1 \mathrm{H}, \mathrm{m}, \mathrm{H}-10], 4.83[1 \mathrm{H}, \mathrm{d}, \mathrm{C} 10-\mathrm{OH}$, $J=5.1 \mathrm{~Hz}], 5.96[1 \mathrm{H}, \mathrm{s}, \mathrm{C} 3-\mathrm{OH}], 6.87[1 \mathrm{H}, \mathrm{d}, \mathrm{H}-7, J=$ $7.7 \mathrm{~Hz}], 6.94[1 \mathrm{H}, \mathrm{t}, \mathrm{H}-5, J=7.5 \mathrm{~Hz}], 7.18[1 \mathrm{H}, \mathrm{t}, \mathrm{H}-6$, $J=7.6 \mathrm{~Hz}], 7.26[1 \mathrm{H}, \mathrm{d}, \mathrm{H}-4, J=7.3 \mathrm{~Hz}], 9.97[1 \mathrm{H}, \mathrm{sl}, \mathrm{NH}]$. ${ }^{13} \mathrm{C}$ NMR (75.5 MHz, $\left.\mathrm{CDCl}_{3}, \mathrm{DMSO}-\mathrm{d}_{6}\right): \delta 18.2[\mathrm{p}, \mathrm{C}-11]$, 43.8 [s, C-8], 71.8 [t, C-10], 72.4 [q, C-3], 109.0 [t, C-7], 120.8 [t, C-5], 122.6 [t, C-6], 128.2 [t, C-4], 129.9 [q, C-3a], 141.2 [q, C-7a], 177.7 [q, C-2], 209.7 [q, C-9]. Elemental analysis: $\mathrm{C}_{12} \mathrm{H}_{13} \mathrm{NO}_{4}$, calcd: $\mathrm{C}: 61.27, \mathrm{H}: 5.57, \mathrm{~N}: 5.95$, obs.: C: 61.25 , H: 5.66, N: 5.76.

4.4.2. Characterization data for the EtOAc soluble diastereoisomer (2p). Yield $14 \%$; mp $116-169^{\circ} \mathrm{C}$. IR $\left(\mathrm{cm}^{-1}\right)$ : 3420, 3357, 3263, 2988, 2918, 1729, 1704, 1622, 1472, 1347, 1186, 1115, 999, 779, 756. Mass, $\mathrm{m} / \mathrm{z}(\%): 235$ $\left(\mathrm{M}^{+*}, 5\right), 207$ (5), 191 (5), 162 (100), 148 (84), 147 (10), 146 (54), 120 (28), 119 (17), 92 (28), 65 (22). ${ }^{1} \mathrm{H}$ NMR $\left(300 \mathrm{MHz}, \mathrm{CDCl}_{3}, \mathrm{DMSO}-\mathrm{d}_{6}\right): \delta 1.26[3 \mathrm{H}, \mathrm{d}, \mathrm{H}-11, J=$ $7.0 \mathrm{~Hz}], 3.17[1 \mathrm{H}, \mathrm{d}, \mathrm{H}-8, J=16.7 \mathrm{~Hz}], 3.42\left[1 \mathrm{H}, \mathrm{d}, \mathrm{H}-8^{\prime}\right.$, $J=16.7 \mathrm{~Hz}], 4.13[1 \mathrm{H}, \mathrm{qd}, \mathrm{H}-10, J=4.8,7.0 \mathrm{~Hz}], 4.66[1 \mathrm{H}$, d, C10-OH, $J=4.8 \mathrm{~Hz}], 5.92[1 \mathrm{H}, \mathrm{s}, \mathrm{C} 3-\mathrm{OH}], 6.87[1 \mathrm{H}, \mathrm{d}$, $\mathrm{H}-7, J=7.7 \mathrm{~Hz}], 6.95[1 \mathrm{H}, \mathrm{t}, \mathrm{H}-5, J=7.6 \mathrm{~Hz}], 7.19[1 \mathrm{H}, \mathrm{td}$, $\mathrm{H}-6, J=1.2,7.7 \mathrm{~Hz}], 7.27[1 \mathrm{H}, \mathrm{dl}, \mathrm{H}-4, J=7.1 \mathrm{~Hz}], 9.87$ $[1 \mathrm{H}, \mathrm{sl}, \mathrm{NH}] .{ }^{13} \mathrm{C}$ NMR $\left(75.5 \mathrm{MHz}, \mathrm{CDCl}_{3}, \mathrm{DMSO}_{-}\right): \delta$ 18.6 [p, C-11], 44.2 [s, C-8], 72.5 [t, C-10], 73.0 [q, C-3], 
109.6 [t, C-7], 121.4 [t, C-5], 123.1 [t, C-6], 128.8 [t, C-4], 130.0 [q, C-3a], 141.4 [q, C-7a], 178.1 [q, C-2], 210.1 [q, C-9]. Elemental analysis: $\mathrm{C}_{12} \mathrm{H}_{13} \mathrm{NO}_{4}$, calcd: C: $61.27, \mathrm{H}$ : 5.57, N: 5.95, obs.: C: 61.46, H: 5.62, N: 5.73.

\subsection{Synthesis of compounds $2 q, 2 r$ and $2 s$, methyl (1-alkyl-3-hydroxy-2-oxindol-3-yl)-acetates. General procedure}

The 1-alkylisatin derivatives $(5.0 \mathrm{mmol})$ were solubilised in a mixture of pyridine and EtOH $(20 \mathrm{ml}, 1: 3 \mathrm{v} / \mathrm{v})$, to which was added a slight excess of malonic acid (6-7 mmol). The reaction mixture was refluxed for $20 \mathrm{~h}$, after which time TLC revealed the complete consumption of the starting material. The reaction mixture was evaporated under reduced pressure to give a solid. This was washed with dilute aqueous $\mathrm{HCl}(25 \mathrm{ml}, 0.25 \mathrm{M})$, filtered and air-dried. The crude product was solubilised in $\mathrm{MeOH}(20 \mathrm{ml})$ and cooled on an ice water bath. Thionyl chloride $(2 \mathrm{ml})$ was added dropwise to the solution. The reaction mixture was allowed to warm to room temperature and left stirring overnight. The crude products were isolated by evaporation of the reaction mixtures under reduced pressure.

4.5.1. Methyl ( $N$-methyl-3-hydroxy-2-oxindol-3-yl)-acetate (2q). The title compound was purified by filtration through a column of silica using hexane/EtOAc $(1: 1 \mathrm{v} / \mathrm{v})$ as eluent. Yield: $80 \%$; $\mathrm{mp} 191-193^{\circ} \mathrm{C}$. IR $\left(\mathrm{cm}^{-1}\right)$ : $3297,2959,1742$, 1695, 1617, 1473, 1434, 1388, 1349, 1203, 1098, 787, 760. Mass, $m / z$ (\%): $235\left(\mathrm{M}^{+*}, 39\right), 175$ (18), 162 (100), $146(10)$, 134 (15), 105 (13), 104 (10), 77 (16). ${ }^{1} \mathrm{H}$ NMR (300 MHz, $\mathrm{CDCl}_{3}, \mathrm{DMSO}_{\mathrm{d}}$ ): $\delta 3.05[1 \mathrm{H}, \mathrm{d}, \mathrm{H}-8, J=15.7 \mathrm{~Hz}], 3.13$ $\left[1 \mathrm{H}, \mathrm{d}, \mathrm{H}-8^{\prime}, J=15.7 \mathrm{~Hz}\right], 3.19$ [3H, s, H-11, N-CH $], 3.46$ [3H, s, H-10, O- $\left.\mathrm{CH}_{3}\right], 6.15[1 \mathrm{H}, \mathrm{s}, \mathrm{OH}], 6.86[1 \mathrm{H}, \mathrm{d}, \mathrm{H}-7$, $J=7.8 \mathrm{~Hz}$ ], $7.04[1 \mathrm{H}, \mathrm{t}, \mathrm{H}-5, J=7.8 \mathrm{~Hz}], 7.31[1 \mathrm{H}, \mathrm{td}, \mathrm{H}-6$, $J=1.1,7.8 \mathrm{~Hz}], 7.36[1 \mathrm{H}, \mathrm{d}, \mathrm{H}-4, J=7.8 \mathrm{~Hz}] .{ }^{13} \mathrm{C} \mathrm{NMR}$ $\left(75.5 \mathrm{MHz}, \mathrm{CDCl}_{3}, \mathrm{DMSO}_{6}\right.$ ): $\delta 25.3[\mathrm{p}, \mathrm{C}-11], 41.0[\mathrm{~s}$, C-8], 50.7 [p, C-10], 72.0 [q, C-3], 107.4 [t, C-7], 121.7 [t, C-5], 122.8 [t, C-6], 128.8 [t, C-4], 129.2 [q, C-3a], 143.1 [q, C-7a], 168.6 [q, C-9], 175.9 [q, C-2].

4.5.2. Methyl ( $N$-benzyl-3-hydroxy-2-oxindol-3-yl)-acetate (2r). The title compound was purified by filtration through a column of silica using hexane/EtOAc $(1: 1 \mathrm{v} / \mathrm{v})$ as eluent. Yield 84\%; mp $137-139^{\circ} \mathrm{C}$. IR $\left(\mathrm{cm}^{-1}\right): 3316,3054,2953$, 1737, 1698, 1617, 1495, 1468, 1429, 1352, 1210, 1183, 1074, 1010, 761, 734, 645. Mass, $\mathrm{m} / \mathrm{z}(\%): 311\left(\mathrm{M}^{+*}, 62\right)$, 293 (8), 238 (18), 234 (13), 220 (10), 180 (8), 146 (100), 91 (97), 65 (11). ${ }^{1} \mathrm{H}$ NMR (300 MHz, $\left.\mathrm{CDCl}_{3}, \mathrm{DMSO}_{6}\right): \delta$ $3.11[1 \mathrm{H}, \mathrm{d}, \mathrm{H}-8, J=15.7 \mathrm{~Hz}], 3.20\left[1 \mathrm{H}, \mathrm{d}, \mathrm{H}-8^{\prime}, J=\right.$ $15.7 \mathrm{~Hz}], 3.42\left[3 \mathrm{H}, \mathrm{s}, \mathrm{H}-10, \mathrm{OCH}_{3}\right], 4.85$ [1H, d, H-11, $J=15.8 \mathrm{~Hz}$ ], $4.92\left[1 \mathrm{H}, \mathrm{d}, \mathrm{H}-11^{\prime}, J=15.8 \mathrm{~Hz}\right], 6.35$ [1H, bs, $\mathrm{OH}], 6.70[1 \mathrm{H}, \mathrm{d}, \mathrm{H}-7, J=7.8 \mathrm{~Hz}], 7.00[1 \mathrm{H}, \mathrm{t}, \mathrm{H}-5$, $J=7.8 \mathrm{~Hz}], 7.18[1 \mathrm{H}, \mathrm{td}, \mathrm{H}-6, J=1.1,7.8 \mathrm{~Hz}], 7.2-7.4[6 \mathrm{H}$, $\mathrm{m}] ;{ }^{13} \mathrm{C}^{13} \mathrm{C}$ NMR $\left(75.5 \mathrm{MHz}, \mathrm{CDCl}_{3}, \mathrm{DMSO}_{-} \mathrm{d}_{6}\right): \delta 40.7[\mathrm{~s}$, C-8], 42.4 [s, C-11], 50.4 [p, C-10], 71.7 [q, C-3], 108.0 [t, C-7], 121.4 [t, C-5], 122.7 [t, C-6], 126.3* [t, C-13], 126.4* [t, C-14], 127.5* [t, C-15], 128.4 [t, C-4], 129.1 [q, C-3a], 134.8 [q, C-12], 142.1 [q, C-7a], 168.2 q, C-9], 175.7 [q, $\mathrm{C}-2]$. The assignments of the signals marked by an * may be interchanged.

4.5.3. Methyl (N-benzyl-3-hydroxy-7-ethyl-2-oxindol-3- yl)-acetate (2s). The title compound was purified by silica gel column chromatography using hexane/EtOAc $(1: 1 \mathrm{v} / \mathrm{v})$ as eluent. Yield $82 \%$; mp $138-139^{\circ} \mathrm{C}$. IR $\left(\mathrm{cm}^{-1}\right): 3312$, 3032, 2974, 1744, 1701, 1605, 1454, 1387, 1358, 1297, $1270,1165,1046,809,753,729,698$. Mass, $\mathrm{m} / \mathrm{z}(\%): 339$ $\left(\mathrm{M}^{+}, 6\right), 174$ (38), 91 (100). ${ }^{1} \mathrm{H}$ NMR (300 MHz, $\left.\mathrm{CDCl}_{3}\right): \delta$ 1.06 [3H, t, H12, $J=7.5 \mathrm{~Hz}], 2.56[2 \mathrm{H}, \mathrm{q}, \mathrm{H} 11, J=7.5 \mathrm{~Hz}]$, $2.97[1 \mathrm{H}, \mathrm{d}, \mathrm{H} 8, J=15.7 \mathrm{~Hz}], 3.08\left[1 \mathrm{H}, \mathrm{d}, \mathrm{H} 8^{\prime}, J=15.7 \mathrm{~Hz}\right]$, 3.69 [3H, s, H10], 4.61 [1H, bs, OH], 5.14 [2H, s, H13], 7.06 [2H, m, CH aromatic], 7.22-7.35 [6H, m, CH aromatic]. ${ }^{13} \mathrm{C}$ NMR $\left(75.5 \mathrm{MHz}, \mathrm{CDCl}_{3}\right): \delta 16.6[\mathrm{p}, \mathrm{C}-12], 24.6[\mathrm{~s}$, $\mathrm{C}-11], 41.5$ [s, $\mathrm{CH}_{2}$ ] 45.6 [s, $\mathrm{CH}_{2}$ ], 52.4 [p, C-10], 72.8 [q, C-3], $121.9[\mathrm{CH}], 123.8[\mathrm{CH}], 125.9[\mathrm{CH}], 127.3[\mathrm{C}], 127.5$ $[\mathrm{CH}], 129.1[\mathrm{CH}], 130.3[\mathrm{C}], 132.7[\mathrm{CH}], 137.1[\mathrm{C}], 140.0$ [C], 171.0 [q, $\mathrm{C}=\mathrm{O}$ ester], 178.0 [q, $\mathrm{C}=\mathrm{O}$ amide].

4.5.4. Ethyl (3-hydroxy-7-ethyl-2-oxindol-3-yl)-acetate (2t). The general procedure for the synthesis of compounds 2q, 2r and $2 \mathbf{s}$ was adapted by using the mono-potassium ethyl malonate salt (10\% excess) in place of malonic acid. The solvent used was a mixture of $\mathrm{EtOH}$, pyridine and acetic acid (15:5:2 v/v/v). Reflux was maintained until complete consumption of the respective isatin derivative was observed. The crude reaction product was isolated as described for compounds $\mathbf{2 q}, \mathbf{2 r}$ and $\mathbf{2 s}$.

The title compound was purified by silica gel column chromatography using hexane/EtOAc $(1: 1 \mathrm{v} / \mathrm{v})$ as eluent. Yield $78 \%$; mp $115-116^{\circ} \mathrm{C}$. IR $\left(\mathrm{cm}^{-1}\right): 3354,3201,3078$, 2983, 2938, 2905, 1737, 1703, 1629, 1607, 1456, 1258, 1187, 1034, 820, 807, 752, 709. ${ }^{1} \mathrm{H}$ NMR $(200 \mathrm{MHz}$, $\left.\mathrm{CDCl}_{3}\right): \delta 1.15[3 \mathrm{H}, \mathrm{t}, \mathrm{H}-11, J=7.1 \mathrm{~Hz}], 1.23[3 \mathrm{H}, \mathrm{t}, \mathrm{H}-13$, $J=7.5 \mathrm{~Hz}$ ], $2.61[2 \mathrm{H}, \mathrm{q}, \mathrm{H}-12, J=7.5 \mathrm{~Hz}], 2.94$ [2H, s, H-8], $4.13[2 \mathrm{H}, \mathrm{q}, \mathrm{H}-10, J=7.1 \mathrm{~Hz}], 7.01[1 \mathrm{H}, \mathrm{t}, \mathrm{H}-5, J=7.3 \mathrm{~Hz}]$, $7.13[1 \mathrm{H}, \mathrm{d}, \mathrm{H}-4$ or $6, J=7.2 \mathrm{~Hz}], 7.23[1 \mathrm{H}, \mathrm{d}, \mathrm{H}-4$ or 6 , $J=7.3 \mathrm{~Hz}], 9.12[1 \mathrm{H}, \mathrm{bs}, \mathrm{NH}] .{ }^{13} \mathrm{C} \mathrm{NMR}\left(50 \mathrm{MHz}, \mathrm{CDCl}_{3}\right)$ : $\delta 14.1\left[\mathrm{CH}_{3}\right], 14.2\left[\mathrm{CH}_{3}\right], 23.8\left[\mathrm{CH}_{2}\right], 41.3\left[\mathrm{CH}_{2}\right], 61.3$ $\left[\mathrm{CH}_{2} \mathrm{O}\right], 74.5[\mathrm{C}-3], 121.8[\mathrm{CH}], 123.5[\mathrm{CH}], 126.4[\mathrm{C}]$, $129.6[\mathrm{C}], 129.8[\mathrm{CH}], 138.9[\mathrm{C}], 170.6[\mathrm{C}=\mathrm{O}$, ester], 179.4 $[\mathrm{C}=\mathrm{O}$, amide $]$.

\subsection{Synthesis of tryptophol derivatives (3), general experimental procedure}

The appropriate aldol derivative $(10 \mathrm{mmol})$ was solubilised in dry THF $(20 \mathrm{ml})$ under a nitrogen atmosphere. To the solution/suspension was added via a syringe a solution of $\mathrm{BH}_{3}$.THF (1 M, 3 or 4 mol equiv.). The reaction mixture was stirred at room temperature until TLC revealed complete consumption of the starting material (generally 2 to $3 \mathrm{~h}$ ). The reaction mixture was added to ethyl acetate $(50 \mathrm{ml})$ and dilute aqueous $\mathrm{HCl}(0.3 \mathrm{M}, 50 \mathrm{ml})$. The phases were mixed and separated. The aqueous phase was extracted with more ethyl acetate $(50 \mathrm{ml})$. The combined organic phases were further washed with aqueous $\mathrm{HCl}(0.3 \mathrm{M}$, $50 \mathrm{ml})$ and water $(50 \mathrm{ml})$, then dried over $\mathrm{Na}_{2} \mathrm{SO}_{4}$, filtered and evaporated under reduced pressure to yield the crude product.

Alternatively, $6 \mathrm{M} \mathrm{HCl}$ was added dropwise with caution to the reaction mixture whilst being cooled on an ice water bath until no further effervescence was observed. The reaction mixture was neutralised by dropwise addition of 
$3 \mathrm{M} \mathrm{NaOH}$. The product was isolated by partitioning the reaction between water and ethyl acetate, then dried over $\mathrm{Na}_{2} \mathrm{SO}_{4}$, filtered and evaporated under reduced pressure to yield the crude product.

Subsequent purification of the tryptophols was achieved by filtration through short columns of silica as indicated for each compound.

4.6.1. 3-(2-Hydroxypropyl)-indole (3a). Purified by filtration through a short column of silica using $\mathrm{CH}_{2} \mathrm{Cl}_{2}$ as eluent. Yield $90 \%$; mp $53-54^{\circ} \mathrm{C}$; lit. $52-55$; $^{12 \mathrm{a}} 44-45 ;{ }^{54}$ $40-41^{\circ} \mathrm{C} .{ }^{24 \mathrm{~b}}$ IR $\left(\mathrm{cm}^{-1}\right)$ : 3521, 3443, 3300, 3248, 3057, 2970, 2925, 2901, 1439, 1355, 1338, 1249, 1228, 1099, $1047,926,800,739$. Mass, $m / z(\%): 175\left(\mathrm{M}^{+\cdot}, 21\right), 130$ (100), 103 (8), 77 (14). ${ }^{1} \mathrm{H}$ NMR (300 MHz, $\left.\mathrm{CDCl}_{3}\right): \delta 1.32$ $[3 \mathrm{H}, \mathrm{d}, \mathrm{H}-10, J=6.15 \mathrm{~Hz}], 1.79[1 \mathrm{H}, \mathrm{bs}, \mathrm{OH}], 2.83[1 \mathrm{H}$, ddd, $\mathrm{H}-8, J=0.6,8.3,14.3 \mathrm{~Hz}$ ], 3.01 [1H, ddd, H-8 $, J=0.9,4.4$, $14.3 \mathrm{~Hz}], 4.14[1 \mathrm{H}, \mathrm{m}, \mathrm{H}-9, \mathrm{CHOH}], 7.08$ [1H, d, H-2, $J=2.3 \mathrm{~Hz}], 7.15[1 \mathrm{H}, \mathrm{td}, \mathrm{H}-5, J=1.2,7.0 \mathrm{~Hz}], 7.23[1 \mathrm{H}, \mathrm{td}$, $\mathrm{H}-6, J=1.2,7.0 \mathrm{~Hz}], 7.38[1 \mathrm{H}, \mathrm{dt}, \mathrm{H}-7, J=0.9,8.0 \mathrm{~Hz}], 7.64$ $[1 \mathrm{H}, \mathrm{d}, \mathrm{H}-4, J=7.8 \mathrm{~Hz}], 8.14[1 \mathrm{H}, \mathrm{bs}, \mathrm{NH}] .{ }^{13} \mathrm{C}$ NMR $\left(75.5 \mathrm{MHz}, \mathrm{CDCl}_{3}\right): \delta 22.6$ [p, C-10], 35.2 [s, C-8], 67.6 $[\mathrm{t}, \mathrm{C}-9, \mathrm{CHOH}], 111.1$ [t, C-7], 112.3 [q, C-3], 118.9 [t, C-5], 119.4 [t, C-4], 122.1 [t, C-6], 122.7 [t, C-2], 127.5 [q, C-3a], 136.3 [q, C-7a]. Elemental analysis: $\mathrm{C}_{11} \mathrm{H}_{13} \mathrm{NO}$, calcd: C: 75.40, H: 7.48, N: 7.99, obs.: C: 75.29, H: 7.69, N: 7.91 .

4.6.2. 3-(2-Hydroxypropyl)- $N$-methylindole (3b). Purified by filtration through a short column of silica using $\mathrm{CH}_{2} \mathrm{Cl}_{2}$ as eluent, $89 \%$ yield. Mp $74-75^{\circ} \mathrm{C}$; lit. ${ }^{55} 75-76^{\circ} \mathrm{C}$. IR $\left(\mathrm{cm}^{-1}\right)$ : 3326, 3051, 2959, 2919, 2866, 1615, 1475, 1372, 1328, 1250, 1080, 938, 735. Mass, $m / z(\%): 189\left(\mathrm{M}^{+*}, 17\right)$, 144 (100), 129 (4), 115 (3), 102 (5), 77 (5). ${ }^{1} \mathrm{H}$ NMR $\left(300 \mathrm{MHz}, \mathrm{CDCl}_{3}\right): \delta 1.27[3 \mathrm{H}, \mathrm{d}, \mathrm{H}-10, J=6.1 \mathrm{~Hz}], 1.79$ $[1 \mathrm{H}, \mathrm{bs}, \mathrm{OH}], 2.77[1 \mathrm{H}, \mathrm{dd}, \mathrm{H}-8, J=8.2,14.3 \mathrm{~Hz}], 2.95[1 \mathrm{H}$, dd, $\mathrm{H}-8^{\prime}, J=4.3,14.3 \mathrm{~Hz}$ ], 3.73 [3H, s, H-11, N-CH $\mathrm{CH}_{3}$, 4.07 [1H, m, H-9], 6.91 [1H, s, H-2], $7.11[1 \mathrm{H}, \mathrm{t}, \mathrm{H}-5, J=7.9 \mathrm{~Hz}$, 7.20-7.30 [2H, m, H-6 and H-7], $7.59[1 \mathrm{H}, \mathrm{d}, \mathrm{H}-4$, $J=7.9 \mathrm{~Hz}] .{ }^{13} \mathrm{C} \mathrm{NMR}\left(75.5 \mathrm{MHz}, \mathrm{CDCl}_{3}\right): \delta 22.6[\mathrm{p}, \mathrm{C}-10]$, 32.5 [p, C-11, $\mathrm{NCH}_{3}$ ], 35.0 [s, C-8], 67.6 [t, C-9, CHOH], 109.1 [t, C-7], 110.6 [q, C-3], 118.8 [t, C-5], 118.9 [t, C-4], 121.6 [t, C-6], 127.5 [t, C-2], 127.9 [q, C-3a], 137.0 [q, C-7a]. Elemental analysis: $\mathrm{C}_{12} \mathrm{H}_{15} \mathrm{NO}$, calcd: C: 76.16, $\mathrm{H}$ : 7.99, N: 7.40, obs.: C: 75.72, H: 8.26, N: 7.30.

4.6.3. 3-(2-Hydroxypropyl)-5-iodoindole (3c). Purified by filtration through a short column of silica using $\mathrm{CH}_{2} \mathrm{Cl}_{2}$ as eluent, $86 \%$ yield. $\mathrm{Mp} 93-95^{\circ} \mathrm{C}$. IR $\left(\mathrm{cm}^{-1}\right): 3519,3252$, 2964, 2910, 1458, 1233, 1101, 1042, 931, 872, 795. Mass, $\mathrm{m} / \mathrm{z}(\%): 301\left(\mathrm{M}^{+\cdot}, 46\right), 256$ (100), $129(48), 102(12) .{ }^{1} \mathrm{H}$ NMR $\left(300 \mathrm{MHz}, \mathrm{CDCl}_{3}\right): \delta 1.28[3 \mathrm{H}, \mathrm{d}, \mathrm{H}-10, J=6.15 \mathrm{~Hz}]$, $1.73[1 \mathrm{H}, \mathrm{s}, \mathrm{OH}], 2.75[1 \mathrm{H}, \mathrm{dd}, \mathrm{H}-8, J=8.2,14.4 \mathrm{~Hz}], 2.90$ $\left[1 \mathrm{H}, \mathrm{dd}, \mathrm{H}-8^{\prime}, J=4.3,14.4 \mathrm{~Hz}\right], 4.08[1 \mathrm{H}, \mathrm{m}, \mathrm{H}-9], 7.02[1 \mathrm{H}$, d, H-2, $J=2.0 \mathrm{~Hz}], 7.13[1 \mathrm{H}, \mathrm{d}, \mathrm{H}-7, J=8.5 \mathrm{~Hz}], 7.43[1 \mathrm{H}$, dd, H-6, $J=1.4,8.5 \mathrm{~Hz}$ ], 7.94 [1H, sl, H-4], 8.22 [1H, bs, $\mathrm{NH}] .{ }^{13} \mathrm{C}$ NMR $\left(75.5 \mathrm{MHz}, \mathrm{CDCl}_{3}\right): \delta 23.1$ [p, C-10], 35.2 [s, C-8], 67.9 [t, C-9, CHOH] 83.1 [q, C-5, C-I], 112.1 [q, C-3], 113.4 [t, C-7], 123.8 [t, C-2], 128.1 [t, C-4], 130.4 [q, C-3a], 130.6 [t, C-6], 135.6 [q, C-7a]. Elemental analysis: $\mathrm{C}_{11} \mathrm{H}_{12} \mathrm{INO}$, calcd: $\mathrm{C}: 43.88, \mathrm{H}: 4.02, \mathrm{~N}: 4.65$, obs.: C: 43.74, H: 4.08, N: 4.42 .
4.6.4. 3-(2-Hydroxypropyl)-5-nitroindole (3d). Purified by filtration through a short column of silica using $\mathrm{CH}_{2} \mathrm{Cl}_{2}$ and EtOAc $(3: 2 \mathrm{v} / \mathrm{v})$ as eluent, $66 \%$ yield. Mp $155-157^{\circ} \mathrm{C}$. IR $\left(\mathrm{cm}^{-1}\right)$ : 3504, 3228, 2965, 2924, 1619, 1518, 1474, 1327, 1074, 935, 808, 738. Mass, $m / z(\%): 220\left(\mathrm{M}^{+*}, 34\right)$, 175 (81), 159 (48), 146 (4), 129 (100), 117 (7), 102 (15), 89 (5), 75 (7), 63 (6). ${ }^{1} \mathrm{H}$ NMR (300 MHz, $\mathrm{CDCl}_{3}, \mathrm{DMSO}_{6}$ ): $\delta 1.11[3 \mathrm{H}, \mathrm{d}, \mathrm{H}-10, J=6.1 \mathrm{~Hz}], 2.79\left[2 \mathrm{H}, \mathrm{d}, \mathrm{H}-8\right.$ and $\mathrm{H}-8^{\prime}$, $J=6.2 \mathrm{~Hz}$ ], 3.14 [1H, sl, OH], 3.98 [1H, m, H-9], $7.11[1 \mathrm{H}$, d, H-2, $J=1.2 \mathrm{~Hz}$ ], $7.27[1 \mathrm{H}, \mathrm{d}, \mathrm{H}-7, J=9.0 \mathrm{~Hz}], 7.89[1 \mathrm{H}$, dd, H-6, $J=2.0,9.0 \mathrm{~Hz}], 8.46$ [1H, d, H-4, $J=2.0 \mathrm{~Hz}], 10.47$ $[1 \mathrm{H}, \mathrm{sl}, \mathrm{NH}] .{ }^{13} \mathrm{C}$ NMR $\left(75.5 \mathrm{MHz}, \mathrm{CDCl}_{3}, \mathrm{DMSO}_{6}\right): \delta$ 22.9 [p, C-10], 34.8 [s, C-8], 67.5 [t, C-9, CHOH], 111.3 [t, C-7], 114.9 [q, C-3], 116.3 [t, C-2], 116.8 [t, C-4], 126.3 [t, C-6], 127.1 [q, C-3a], 139.6 [q, C-7a], 140.9 [q, C-5, $\left.\mathrm{C}-\mathrm{NO}_{2}\right]$

4.6.5. 3-(2-Hydroxypropyl)-4,6-dibromoindole (3e). Purified by filtration through a short column of silica using $\mathrm{CH}_{2} \mathrm{Cl}_{2}$ as eluent, $90 \%$ yield. $\mathrm{Mp} 125-126^{\circ} \mathrm{C}$. IR $\left(\mathrm{cm}^{-1}\right)$ : 3417, 3259, 2965, 2924, 1638, 1612, 1399, 1261, $1122,1049$, 935, 819. Mass, $m / z \quad \%)$ : $335\left(\mathrm{M}^{+*}\right.$, $\left.\mathrm{C}_{11} \mathrm{H}_{11}^{81} \mathrm{Br}_{2} \mathrm{NO}, 18\right), 333\left(\mathrm{M}^{+*}, 38\right), 331\left(\mathrm{M}^{+*}, 17\right), 288$ (100), 209 (15), 128 (29), 101 (7), 75 (8). ${ }^{1} \mathrm{H}$ NMR $\left(300 \mathrm{MHz}, \mathrm{CDCl}_{3}\right): \delta 1.31[3 \mathrm{H}, \mathrm{d}, \mathrm{H}-10, J=6.1 \mathrm{~Hz}], 1.79$ [1H, bs, OH], $2.84[1 \mathrm{H}, \mathrm{dd}, \mathrm{H}-8, J=8.5,14.5 \mathrm{~Hz}], 3.31[1 \mathrm{H}$, ddd, H-8', $J=0.75,4.0,14.5 \mathrm{~Hz}], 4.18[1 \mathrm{H}, \mathrm{m}, \mathrm{H}-9], 7.04$ [1H, bd, H-2, $J=2.4 \mathrm{~Hz}$ ], 7.37 [1H, d, H-5, $J=1.6 \mathrm{~Hz}$ ], 7.41 $[1 \mathrm{H}, \mathrm{d}, \mathrm{H}-7, J=1.6 \mathrm{~Hz}], 8.42[1 \mathrm{H}, \mathrm{bs}, \mathrm{NH}] .{ }^{13} \mathrm{C} \mathrm{NMR}$ $\left(75.5 \mathrm{MHz}, \mathrm{CDCl}_{3}\right): \delta 22.8$ [p, C-10], 35.9 [s, C-8], 68.7 [t, C-9, CHOH], 113.8 [t, C-7], 114.1 [q, C-3], 114.8 [q, C-4], 115.2 [q, C-6], 124.7 [q, C-3a], 125.5 [t, C-2], 126.8 [t, C-5], 138.4 [q, C-7a]. Elemental analysis: $\mathrm{C}_{11} \mathrm{H}_{11} \mathrm{Br}_{2} \mathrm{NO}$, calcd: C: $39.67, \mathrm{H}: 3.33$, N: 4.21, obs.: C: $39.40, \mathrm{H}: 3.15$, N: 3.95 .

4.6.6. 5,7-Dibromo-3-(2-hydroxypropyl)-indole (3f). Purified by filtration through a short column of silica using $\mathrm{CH}_{2} \mathrm{Cl}_{2}$ as eluent, $92 \%$ yield. Mp $128-130^{\circ} \mathrm{C}$. IR $\left(\mathrm{cm}^{-1}\right)$ : 3529, 3451, 3253, 2964, 1638, 1611, 1399, 1320, 1261, 1180, 1123, 1049, 935, 835, 819. Mass, $\mathrm{m} / \mathrm{z}(\%): 335$ $\left(\mathrm{M}^{+\cdot}, \mathrm{C}_{11} \mathrm{H}_{11}^{81} \mathrm{Br}_{2} \mathrm{NO}, 19\right), 333\left(\mathrm{M}^{+*}, \mathrm{C}_{11} \mathrm{H}_{11}^{79}, 81 \mathrm{Br}_{2} \mathrm{NO}, 40\right)$,

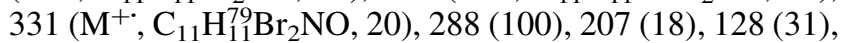
101 (9), 75 (9). ${ }^{1} \mathrm{H}$ NMR (300 MHz, $\mathrm{CDCl}_{3}$ ): $\delta 1.28[3 \mathrm{H}, \mathrm{d}$, $\mathrm{H}-10, J=6.2 \mathrm{~Hz}], 1.67[1 \mathrm{H}, \mathrm{sl}, \mathrm{OH}], 2.76[1 \mathrm{H}, \mathrm{ddd}, \mathrm{H}-8$, $J=0.6,7.9,14.5 \mathrm{~Hz}], 2.89[1 \mathrm{H}$, ddd, H-8 $, J=0.8,4.5$, $14.5 \mathrm{~Hz}$ ], 4.09 [1H, m, H-9], 7.15 [1H, d, H-2, $J=2.3 \mathrm{~Hz}$, $7.47[1 \mathrm{H}, \mathrm{d}, \mathrm{H}-6, J=1.6 \mathrm{~Hz}], 7.70[1 \mathrm{H}, \mathrm{dd}, \mathrm{H}-4, J=0.6$, $1.6 \mathrm{~Hz}], 8.34[1 \mathrm{H}, \mathrm{bs}, \mathrm{NH}] .{ }^{13} \mathrm{C} \mathrm{NMR}\left(75.5 \mathrm{MHz}, \mathrm{CDCl}_{3}\right): \delta$ 23.2 [p, C-10], 35.3 [s, C-8], 67.9 [t, C-9, CHOH], 105.4 [q, C-7], 112.7 [q, C-5], 113.9 [q, C-3], 121.3 [t, C-4], 124.8 [t, C-2], 126.1 [t, C-6], 130.2 [q, C-3a], 134.2 [q, C-7a]. Elemental analysis: $\mathrm{C}_{11} \mathrm{H}_{11} \mathrm{Br}_{2} \mathrm{NO}$, calcd: C: $39.67, \mathrm{H}: 3.33$, $\mathrm{N}: 4.21$, obs.: C: $39.50, \mathrm{H}: 3.21, \mathrm{~N}: 4.03$.

4.6.7. 3-(2-Phenyl-2-hydroxyethyl)-indole ${ }^{23}$ (3g). Purified by filtration through a short column of silica using $\mathrm{CH}_{2} \mathrm{Cl}_{2}$ as eluent, $85 \%$ yield. Obtained as a slightl yellow oil. IR ( $\nu$, $\mathrm{cm}^{-1}$ ): 3405, 3057, 3026, 2933, 2897, 1453, 1420, 1335, 1093, 1061, 1005, 745, 670. Mass, $m / z(\%): 237\left(\mathrm{M}^{+\cdot}, 5\right)$, 219 (12), 130 (100), 77 (18). ${ }^{1} \mathrm{H}$ NMR (300 MHz, $\left.\mathrm{CDCl}_{3}\right): \delta$ 2.17 [1H, bs, OH], 3.10 [1H, ddd, H-8, $J=0.5,8.8,14.5 \mathrm{~Hz}$, $3.23\left[1 \mathrm{H}\right.$, ddd, $\left.\mathrm{H}-8^{\prime}, J=0.8,4.4,14.5 \mathrm{~Hz}\right], 4.99[1 \mathrm{H}$, dd, 
$\mathrm{H}-9, \mathrm{CHOH}, J=4.4,8.8 \mathrm{~Hz}], 6.98$ [1H, d, H-2, $J=2.3 \mathrm{~Hz}]$, $7.12-7.43\left[8 \mathrm{H}, \mathrm{m}, \mathrm{H}-5,6,7,11,11^{\prime}, 12,12^{\prime}, 13\right], 7.60[1 \mathrm{H}$, $\mathrm{dd}, \mathrm{H}-4, J=0.6,7.8 \mathrm{~Hz}], 8.05[1 \mathrm{H}, \mathrm{bs}, \mathrm{NH}] .{ }^{13} \mathrm{C} \mathrm{NMR}$ $\left(75.5 \mathrm{MHz}, \mathrm{CDCl}_{3}\right): \delta 36.1$ [s, C-8], 74.1 [t, C-9, $\mathrm{CHOH}$ ], 111.4 [t, C-7], 112.2 [q, C-3], 119.1 [t, C-5], 119.8 [t, C-4], 122.4 [t, C-6], 123.3 [t, C-2], 126.1 [t, C-11], 127.7 [t, C-13], 128.6 [t, C-12], 136.6 [q, C-3a], 144.3 [q, C-7a]. Elemental analysis: $\mathrm{C}_{16} \mathrm{H}_{15} \mathrm{NO}$, calcd: C: $80.98, \mathrm{H}: 6.32, \mathrm{~N}: 5.90$, obs.: C: $80.72, \mathrm{H}: 6.59, \mathrm{~N}: 5.71$.

4.6.8. 3-(2-Phenyl-2-hydroxyethyl)-4,6-dibromoindole (3h). Purified by filtration through a short column of silica using $\mathrm{CH}_{2} \mathrm{Cl}_{2}$ as eluent, $88 \%$ yield. $\mathrm{Mp} 151-152^{\circ} \mathrm{C}$. IR $\left(\mathrm{cm}^{-1}\right)$ : 3501, 3233, 3024, 2940, 1610, 1537, 1395, 1319, 1191, 1167, 1049, 999, 804, 746, 699. Mass, $\mathrm{m} / \mathrm{z}(\%): 397$ $\left(\mathrm{M}^{+*}, \mathrm{C}_{16} \mathrm{H}_{13}^{81} \mathrm{Br}_{2} \mathrm{NO}, 5\right), 395\left(\mathrm{M}^{+*}, \mathrm{C}_{16} \mathrm{H}_{13}^{79,81} \mathrm{Br}_{2} \mathrm{NO}, 11\right)$, $393\left(\mathrm{M}^{+}, \mathrm{C}_{16} \mathrm{H}_{13}^{79} \mathrm{Br}_{2} \mathrm{NO}, 6\right), 377$ (46), 288 (100), 217 (21), 207 (10), 189 (7), 128 (22), 107 (26), 79 (18). ${ }^{1} \mathrm{H}$ NMR $\left(300 \mathrm{MHz}, \mathrm{CDCl}_{3}\right): \delta 2.08[1 \mathrm{H}, \mathrm{bs}, \mathrm{OH}], 3.15[1 \mathrm{H}, \mathrm{dd}, \mathrm{H}-8$, $J=9.0,14.6 \mathrm{~Hz}], 3.60\left[1 \mathrm{H}, \mathrm{dd}, \mathrm{H}-8^{\prime}, J=4.1,14.6 \mathrm{~Hz}\right], 5.11$ $[1 \mathrm{H}, \mathrm{dd}, \mathrm{H}-9, J=4.1,9.0 \mathrm{~Hz}], 7.02[1 \mathrm{H}, \mathrm{d}, \mathrm{H}-2, J=2.2 \mathrm{~Hz}]$, 7.29-7.50 [7H, m, H-5, 7, 11, 11' , 12, 12', 13], 8.18 [1H, bs, $\mathrm{NH}] .{ }^{13} \mathrm{C} \mathrm{NMR}\left(75.5 \mathrm{MHz}, \mathrm{CDCl}_{3}\right): \delta 36.4[\mathrm{~s}, \mathrm{C}-8], 74.6[\mathrm{t}$, C-9, $\mathrm{CHOH}$ ], 113.7 [q, C-3], 113.8 [t, C-7], 114.9 [q, C-4], 115.4 [q, C-6], 124.7 [q, C-10], 125.9 [t, C-2], 126.2 [t, C-5], 127.0 [t, C-11], 127.8 [t, C-13], 128.6 [t, C-12], 138.3 [q, C-3a], 144.2 [q, C-7a]; FAB-MS: $\mathrm{C}_{16} \mathrm{H}_{13} \mathrm{Br}_{2} \mathrm{NO}$, calcd: 392.9364, 394.9343, 396.9323, obs.: 396.9360, 392.9352, 394.9345. Elemental analysis: $\mathrm{C}_{16} \mathrm{H}_{13} \mathrm{Br}_{2} \mathrm{NO}$, calcd: $\mathrm{C}$ : 48.64, H: 3.32, N: 3.55, obs.: C: 48.35, H: 3.35, N: 3.39 .

4.6.9. 3-(2-Phenyl-2-hydroxyethyl)-5,7-dibromoindole (3i). Purified by filtration through a short column of silica using $\mathrm{CH}_{2} \mathrm{Cl}_{2}$ as eluent, $90 \%$ yield. $\mathrm{Mp} 120-121^{\circ} \mathrm{C}$. IR $\left(\mathrm{cm}^{-1}\right):$ 3502, 3416, 3329, 3065, 3029, 2922, 2879, 1638, 1556, 1463, 1188, 1111, 1053, 700. Mass, $\mathrm{m} / \mathrm{z}(\%): 397$ $\left(\mathrm{M}^{+*}, \mathrm{C}_{16} \mathrm{H}_{13}^{81} \mathrm{Br}_{2} \mathrm{NO}, 6\right), 395\left(\mathrm{M}^{+*}, \mathrm{C}_{16} \mathrm{H}_{13}^{79,81} \mathrm{Br}_{2} \mathrm{NO}, 13\right)$, $393\left(\mathrm{M}^{+}, \mathrm{C}_{16} \mathrm{H}_{13}^{79} \mathrm{Br}_{2} \mathrm{NO}, 7\right), 377$ (13), 288 (100), 207 (19), 128 (32), 107 (41), 79 (39). ${ }^{1} \mathrm{H}$ NMR (300 MHz, $\left.\mathrm{CDCl}_{3}\right): \delta$ $2.10[1 \mathrm{H}, \mathrm{bs}, \mathrm{OH}], 3.11[1 \mathrm{H}, \mathrm{bd}, \mathrm{H}-8, J=3.0 \mathrm{~Hz}], 3.13[1 \mathrm{H}$, bs, H-8'], $4.96[1 \mathrm{H}, \mathrm{t}, \mathrm{H}-9, J=6.5 \mathrm{~Hz}], 7.05[1 \mathrm{H}, \mathrm{d}, \mathrm{H}-2$, $J=2.3 \mathrm{~Hz}], 7.31-7.38$ [5H, m, H-11, 11', 12, 12', 13], 7.47 $[1 \mathrm{H}, \mathrm{d}, \mathrm{H}-6, J=1.5 \mathrm{~Hz}], 7.58[1 \mathrm{H}, \mathrm{d}, \mathrm{H}-4, J=1.5 \mathrm{~Hz}], 8.25$ $[1 \mathrm{H}, \mathrm{bs}, \mathrm{NH}] .{ }^{13} \mathrm{C} \mathrm{NMR}\left(75.5 \mathrm{MHz}, \mathrm{CDCl}_{3}\right): \delta 35.8[\mathrm{~s}, \mathrm{C}-8]$, 74.3 [t, C-9, CHOH], 105.3 [q, C-7], 112.7 [q, C-5], 113.4 [q, C-3], 121.2 [t, C-4], 125.0 [t, C-2], 126.1 [t, C-6], 126.9 [t, C-11], 128.0 [t, C-13], 128.7 [t, C-12], 130.1 [q, C-10], 134.0 [q, C-3a], 144.0 [q, C-7a, CN]. Elemental analysis: $\mathrm{C}_{16} \mathrm{H}_{13} \mathrm{Br}_{2} \mathrm{NO}$, calcd: C: 48.64, H: 3.32, N: 3.55, obs.: C: 48.35, H: 3.35, N: 3.39 .

4.6.10. trans-3-(2-Hydroxycyclohexyl)-indole (trans-3j). Purified by filtration through a short column of silica using $\mathrm{CH}_{2} \mathrm{Cl}_{2}$ as eluent, $80 \%$ yield. $\mathrm{Mp} 157-160^{\circ} \mathrm{C}$; lit. $157,5^{\circ}$ $160-162 ;{ }^{13 \mathrm{~d}} 166-169^{\circ} \mathrm{C} .{ }^{10} \mathrm{IR}\left(\mathrm{cm}^{-1}\right): 3488,3249,3057$, 2925, 2853, 1442, 1221, 1106, 1026, 947, 868, 797, 734. Mass, $m / z(\%): 215\left(\mathrm{M}^{+}, 62\right), 197$ (10), 168 (8), 156 (49), 143 (17), 130 (100), 117 (14). ${ }^{1} \mathrm{H}$ NMR (300 MHz, $\mathrm{CDCl}_{3}$ ): $\delta 1.43-2.08\left[8 \mathrm{H}, \mathrm{m}, \mathrm{CH}_{2}\right.$ cyclohexanol], $2.18[1 \mathrm{H}, \mathrm{bs}, \mathrm{OH}$, $2.75[1 \mathrm{H}$, ddd, H-8 cyclohexanol, $J=3.5,10.0,12.2 \mathrm{~Hz}]$, $3.78[1 \mathrm{H}, \mathrm{td}, \mathrm{H}-9, \mathrm{CHOH}, J=4.3,10.0 \mathrm{~Hz}], 7.06[1 \mathrm{H}, \mathrm{d}, \mathrm{H}-2$ indole, $J=2.4 \mathrm{~Hz}], 7.14[1 \mathrm{H}, \mathrm{td}, \mathrm{H}-5, J=1.1,7.5 \mathrm{~Hz}], 7.22$ [1H, td, H-6, J=1.1, 7.5 Hz], 7.36 [1H, bd, H-7, J=7.5 Hz],
$7.74[1 \mathrm{H}$, bd, H-4, $J=7.5 \mathrm{~Hz}], 8.27$ [1H, bs, NH]. ${ }^{13} \mathrm{C}$ NMR $\left(75.5 \mathrm{MHz}, \mathrm{CDCl}_{3}\right): \delta 25.0[\mathrm{~s}, \mathrm{C}-11], 26.1$ [s, C-12], 32.5 [s, C-13], 34.1 [s, C-10], 44.3 [t, C-8], 74.6 [t, C-9, CHOH], 111.2 [t, C-7], 117.4 [q, C-3], 119.3 [t, C-5], 119.4 [t, C-4], 121.2 [t, C-6], 122.1 [t, C-2], 126.9 [q, C-3a], 136.4 [q, C-7a]. HRMS: $\mathrm{C}_{14} \mathrm{H}_{17} \mathrm{NO}$, calcd: 215.1311, obs.: 215.1288.

4.6.11. cis-3-(2-Hydroxycyclohexyl)-indole (cis-3j). Purified by filtration through a short column of silica using $\mathrm{CH}_{2} \mathrm{Cl}_{2}$ as eluent, $10 \%$ yield. $\mathrm{Mp} 110-112^{\circ} \mathrm{C}$; lit. ${ }^{10} 115^{\circ} \mathrm{C}$. IR $\left(\mathrm{cm}^{-1}\right)$ : 3529, 3316, 3060, 2928, 2858, 1452, 1433, $1341,1219,984,955,767,737,681$. Mass, $\mathrm{m} / \mathrm{z}(\%): 215$ $\left(\mathrm{M}^{+}, 98\right), 156$ (55), 143 (16), 130 (100), 117 (11). ${ }^{1} \mathrm{H}$ NMR (300 MHz, $\mathrm{CDCl}_{3}$ ): $\delta 1.4-2.1\left[9 \mathrm{H}, \mathrm{m}, \mathrm{CH}_{2}, \mathrm{OH}\right], 3.14[1 \mathrm{H}$, dt, H-8, $J=1.2,11.4 \mathrm{~Hz}], 4.19$ [1H, bs, H-9, CHOH], 7.03 $[1 \mathrm{H}, \mathrm{dd}, \mathrm{H}-2$ indole, $J=0.8,2.4 \mathrm{~Hz}], 7.11[1 \mathrm{H}, \mathrm{td}, \mathrm{H}-5$, $J=1.1,7.0 \mathrm{~Hz}], 7.20[1 \mathrm{H}, \mathrm{td}, \mathrm{H}-6, J=1.1,7.0 \mathrm{~Hz}], 7.35[1 \mathrm{H}$, $\mathrm{m}, \mathrm{H}-7], 7.62$ [1H, m, H-4], 8.15 [1H, bs, NH]. ${ }^{13} \mathrm{C} \mathrm{NMR}$ $\left(75.5 \mathrm{MHz}, \mathrm{CDCl}_{3}\right): \delta 19.7$ [s, C-11], 25.0 [s, C-12], $26.2[\mathrm{~s}$, C-13], 31.8 [s, C-10], 39.5 [t, C-8], 68.2 [t, C-9, CHOH], 111.1 [t, C-7], 118.2 [q, C-3], 118.8 [t, C-5], 119.2 [t, C-4], 121.5 [t, C-6], 122.2 [t, C-2], 126.3 [q, C-3a], 136.4 [q, C-7a].

4.6.12. 3-(3,3-Dimethyl-2-hydroxybutyl)-indole (3k). Purified by filtration through a short column of silica using $\mathrm{CH}_{2} \mathrm{Cl}_{2}$ as eluent, $82 \%$ yield. Mp $121-122^{\circ} \mathrm{C}$; lit. $125-126 ;{ }^{22} 120-122^{\circ} \mathrm{C}^{24 \mathrm{a}}$ IR $\left(\mathrm{cm}^{-1}\right)$ : 3537, 3419, 3266, 2922, 2862, 1619, 1456, 1234, 1100, 1064, 1003, 737. Mass, m/z (\%): $217\left(\mathrm{M}^{+*}, 15\right), 130$ (100), 118 (4), 103 (4), 77 (6). ${ }^{1} \mathrm{H}$ NMR $\left(300 \mathrm{MHz}, \mathrm{CDCl}_{3}\right): \delta 1.05$ [9H, s, H-11, $t$-butyl], $1.67[1 \mathrm{H}, \mathrm{s}, \mathrm{OH}], 2.63$ [1H, dd, H-8, $J=10.9,14.3 \mathrm{~Hz}], 3.10$ $\left[1 \mathrm{H}, \mathrm{bd}, \mathrm{H}-8^{\prime}, J=14.3 \mathrm{~Hz}\right], 3.56[1 \mathrm{H}, \mathrm{dd}, \mathrm{H}-9, J=1.8$, $10.9 \mathrm{~Hz}$ ], 7.07 [1H, d, H-2, J=1.5 Hz], $7.12[1 \mathrm{H}, \mathrm{td}, \mathrm{H}-5$, $J=1.0,7.4 \mathrm{~Hz}], 7.21[1 \mathrm{H}, \mathrm{td}, \mathrm{H}-6, J=1.0,7.5 \mathrm{~Hz}], 7.29[1 \mathrm{H}$, bd, H-7, $J=8.0 \mathrm{~Hz}], 7.60[1 \mathrm{H}, \mathrm{bd}, \mathrm{H}-4, J=7.8 \mathrm{~Hz}], 8.07$ $\left[1 \mathrm{H}\right.$, bs, NH]. ${ }^{13} \mathrm{C}$ NMR $\left(75.5 \mathrm{MHz}, \mathrm{CDCl}_{3}\right): \delta 26.1[\mathrm{p}$, C-11, $t$-butyl], 28.1 [s, C-8], 34.9 [q, C-10], 78.9 [t, C-9, $\mathrm{CHOH}$ ], 111.5 [t, C-7], 113.5 [q, C-3], 119.1 [t, C-5], 119.6 [t, C-4], 122.4 [t, C-6], 122.9 [t, C-2], 127.6 [q, C-3a], 136.8 [q, C-7a]. Elemental analysis: $\mathrm{C}_{14} \mathrm{H}_{19} \mathrm{NO}$, calcd: C: 77.38 , H: 8.81, N: 6.45, obs.: C: 77.47, H: 8.99, N: 6.20.

4.6.13. 3-(3,3-Dimethyl-2-hydroxybutyl)- $N$-methylindole (31). Purified by filtration through a short column of silica using $\mathrm{CH}_{2} \mathrm{Cl}_{2}$ as eluent, $80 \%$ yield. $\mathrm{Mp} 49-50^{\circ} \mathrm{C}$. IR $\left(\mathrm{cm}^{-1}\right)$ : 3564, 3057, 2953, 2863, 1482, 1358, 1327, 1252, 1153, 1122, 1069, 1005, 821, 735. Mass, $m / z(\%): 231\left(\mathrm{M}^{+*}\right.$, 9), 144 (100), 84 (6), 77 (6). ${ }^{1} \mathrm{H} \mathrm{NMR}\left(300 \mathrm{MHz}, \mathrm{CDCl}_{3}\right): \delta$ 1.04 [9H, s, H-11, $t$-butyl], $1.65[1 \mathrm{H}, \mathrm{s}, \mathrm{OH}], 2.65[1 \mathrm{H}, \mathrm{dd}$, $\mathrm{H}-8, J=10.9,14.3 \mathrm{~Hz}], 3.08\left[1 \mathrm{H}, \mathrm{dd}, \mathrm{H}-8^{\prime}, J=1.5,14.3 \mathrm{~Hz}\right]$, $3.53[1 \mathrm{H}, \mathrm{dd}, \mathrm{H}-9, J=1.5,10.9 \mathrm{~Hz}], 3.75[3 \mathrm{H}, \mathrm{s}, \mathrm{H}-12$, $\left.\mathrm{NCH}_{3}\right], 6.96$ [1H, s, H-2], 7.11 [1H, td, H-5, J=1.1, 7.6 Hz], $7.24[1 \mathrm{H}, \mathrm{td}, \mathrm{H}-6, J=1.0,7.6 \mathrm{~Hz}], 7.30[1 \mathrm{H}, \mathrm{bd}, \mathrm{H}-7$, $J=7.6 \mathrm{~Hz}], 7.59[1 \mathrm{H}$, bd, H-4, $J=7.6 \mathrm{~Hz}] .{ }^{13} \mathrm{C} \mathrm{NMR}$ $\left(75.5 \mathrm{MHz}, \mathrm{CDCl}_{3}\right): \delta 26.1$ [p, C-11, $t$-butyl], 28.0 [s, C-8], 32.8 [p, C-12], 34.9 [q, C-10], 79.1 [t, C-9, CHOH], 109.5 [t, C-7], 111.9 [q, C-3], 119.0 [t, C-5], 119.2 [t, C-4], 122.0 [t, C-6], 127.7 [t, C-2], 128.3 [q, C-3a], 137.5 [q, C-7a, C-N]. Elemental analysis: $\mathrm{C}_{15} \mathrm{H}_{21} \mathrm{NO}$, calcd: C: 77.88, H: 9.15, N: 6.05, obs.: C: 77.74, H: 8.93, N: 5.88 .

4.6.14. 3-(2-Phenyl-2-hydroxyethyl)- $N$-benzylindole (3m). Purified by filtration through a short column of silica 
using $\mathrm{CH}_{2} \mathrm{Cl}_{2}$ as eluent, $80 \%$ yield. Obtained as an oil. IR $\left(\mathrm{cm}^{-1}\right)$ : 3547, 3404, 3060, 3029, 2914, 1614, 1495, 1467, 1454, 1357, 1333, 1200, 1182, 1047, 1028, 1014, 740, 700. Mass, $m / z(\%): 327\left(\mathrm{M}^{+*}, 7\right), 309$ (28), 279 (10), 220 (81), 167 (22), 149 (84), 91 (100), 71 (34). ${ }^{1} \mathrm{H}$ NMR (300 MHz, $\left.\mathrm{CDCl}_{3}\right): \delta 2.13[1 \mathrm{H}, \mathrm{d}, \mathrm{OH}, J=2.7 \mathrm{~Hz}], 3.11[1 \mathrm{H}, \mathrm{dd}, \mathrm{H}-8$, $J=8.6,14.5 \mathrm{~Hz}], 3.23\left[1 \mathrm{H}, \mathrm{dd}, \mathrm{H}-8^{\prime}, J=4.6,14.5 \mathrm{~Hz}\right], 5.00$ $[1 \mathrm{H}, \mathrm{dd}, \mathrm{H}-9, J=4.6,8.6 \mathrm{~Hz}], 5.26\left[2 \mathrm{H}, \mathrm{s}, \mathrm{H}-14, \mathrm{CH}_{2}\right.$ benzilic], $6.92[1 \mathrm{H}, \mathrm{s}, \mathrm{H}-2], 7.07-7.41[13 \mathrm{H}, \mathrm{m}, \mathrm{CH}$ aromatic], $7.63[1 \mathrm{H}, \mathrm{d}, \mathrm{H}-4, \quad J=7.4 \mathrm{~Hz}] .{ }^{13} \mathrm{C} \quad \mathrm{NMR}$ $\left(75.5 \mathrm{MHz}, \mathrm{CDCl}_{3}\right): \delta 36.1$ [s, C-8], 50.1 [s, C-14], 74.2 [t, C-9, CHOH], 110.0 [t, C-7], 111.2 [q, C-3], 119.3 [t, C-5], 119.5 [t, C-4], 122.2 [t, C-6], 126.1 [t, C-11], 127.0 [t, C-16], 127.4 [t, C-17], 127.7 [t, C-13], 127.8 [t, C-2], 128.4 [q, C10], 128.6 [t, C-12], 129.0 [t, C-18], 136.9 [q, C-15], 137.7 [q, C-3a], 144.3 [q, C-7a]. Elemental analysis: $\mathrm{C}_{23} \mathrm{H}_{21} \mathrm{NO}$, calcd: C: 84.37, H: 6.46, N: 4.28, obs.: C: 83.95, H: 6.28, N: 4.03 .

4.6.15. 3-(2,3-Dihydroxybutyl)-indole (3n). Purified by filtration through a short column of silica using $\mathrm{CH}_{2} \mathrm{Cl}_{2}$ as eluent, $83-5 \%$ yield. Obtained as a colourless oil. IR $\left(\mathrm{cm}^{-1}\right)$ : 3411, 3057, 2972, 2924, 1705, 1619, 1457, 1339, 1230, 1050, 743. Mass, $\mathrm{m} / \mathrm{z}(\%): 205\left(\mathrm{M}^{+*}, 21\right), 160(3), 130$ (100), 118 (5), 103 (3), 77 (4). ${ }^{1} \mathrm{H}$ NMR (300 MHz, $\left.\mathrm{CDCl}_{3}\right)$ : $\delta 1.29[3 \mathrm{H}, \mathrm{d}, \mathrm{H}-11, J=6.1 \mathrm{~Hz}$, major isomer], $1.29[3 \mathrm{H}, \mathrm{d}$, $\mathrm{H}-11, J=6.3 \mathrm{~Hz}$, minor isomer], $2.39[1 \mathrm{H}, \mathrm{bs}, \mathrm{OH}], 2.64$ [1H, bs, OH], $2.82[1 \mathrm{H}, \mathrm{dd}, \mathrm{H}-8, J=8.2,14.6 \mathrm{~Hz}$, major isomer], $2.85[1 \mathrm{H}, \mathrm{d}, \mathrm{H}-8, J=10.2 \mathrm{~Hz}$, minor isomer], 3.01 $\left[1 \mathrm{H}, \mathrm{d}, \mathrm{H}-8^{\prime}, J=3.2 \mathrm{~Hz}\right.$, minor isomer], $3.05\left[1 \mathrm{H}, \mathrm{dd}, \mathrm{H}-8^{\prime}\right.$, $J=3.8,14.6 \mathrm{~Hz}$, major isomer], 3.65-3.77 [2H, m, H-9 and $\mathrm{H}-10$, major isomer], 3.88-3.92 [2H, m, H-9 and $\mathrm{H}-10$, minor isomer], $7.04[1 \mathrm{H}, \mathrm{d}, \mathrm{H}-2, J=2.4 \mathrm{~Hz}], 7.16[1 \mathrm{H}, \mathrm{td}$, $\mathrm{H}-5, J=1.2,7.5 \mathrm{~Hz}], 7.22$ [1H, td, H-6, $J=1.2,7.5 \mathrm{~Hz}], 7.36$ [1H, bd, H-7, $J=7.5-8.0 \mathrm{~Hz}], 7.62[1 \mathrm{H}, \mathrm{bd}, \mathrm{H}-4, J=7.5-$ $8.0 \mathrm{~Hz}], 8.25[1 \mathrm{H}, \mathrm{bs}, \mathrm{NH}] .{ }^{13} \mathrm{C} \mathrm{NMR}\left(75.5 \mathrm{MHz}, \mathrm{CDCl}_{3}\right): \delta$ major isomer 19.3 [p, C-11], 29.4 [s, C-8], 70.1 [CHOH], $75.3[\mathrm{CHOH}]$, minor isomer 17.2 [p, C-11], 27.3 [s, C-8], $69.7[\mathrm{CHOH}], 74.4[\mathrm{CHOH}]$, aromatic carbons $111.2[\mathrm{t}$, C-7], 111.4 [q, C-3], 118.7 [t, C-5], 119.4 [t, C-4], 122.1 [t, C-6], 122.8 [t, C-2, CH minor isomer], 122.9 [t, C-2, CH major isomer], 127.3 [q, C-3a], 136.2 [q, C-7a, CN]. HRMS: $\mathrm{C}_{12} \mathrm{H}_{15} \mathrm{NO}_{2}$, calcd: 205.1103, obs.: 205.1120.

4.6.16. 3-(2-Hydroxyethyl)- $N$-methylindole ${ }^{56}$ (3q). Purified by filtration through a short column of silica using $\mathrm{CH}_{2} \mathrm{Cl}_{2}$ as eluent, $87 \%$ yield. Obtained as a slight yellow oil. IR $\left(\mathrm{cm}^{-1}\right)$ : 3363, 3053, 2928, 1726, 1642, 1473, 1378, 1328, 1248, 1045, 740. Mass, $\mathrm{m} / \mathrm{z}(\%): 175\left(\mathrm{M}^{+*}, 24\right), 144$ (100), 115 (4), 102 (4), 77 (5). ${ }^{1} \mathrm{H}$ NMR (200 MHz, $\mathrm{CDCl}_{3}$ ): $\delta 1.69[1 \mathrm{H}, \mathrm{bs}, \mathrm{OH}], 2.99[2 \mathrm{H}, \mathrm{t}, \mathrm{H}-8, J=6.35 \mathrm{~Hz}], 3.72[3 \mathrm{H}$, $\mathrm{s}, \mathrm{H}-10, \mathrm{~N}-\mathrm{CH}_{3}$ ], 3.86 [2H, t, H-9, O- $\mathrm{CH}_{2}, J=6.35 \mathrm{~Hz}$, $6.91[1 \mathrm{H}, \mathrm{s}, \mathrm{H}-2], 7.10$ [1H, ddd, H-5, $J=1.6,6.5,7.0 \mathrm{~Hz}$, 7.24 [2H, m, H-6 e H-7], $7.58[1 \mathrm{H}, \mathrm{d}, \mathrm{H}-4, J=7.0 \mathrm{~Hz}] .{ }^{13} \mathrm{C}$ NMR $\left(50 \mathrm{MHz}, \mathrm{CDCl}_{3}\right): \delta 28.8$ [s, C-8], 32.7 [p, C-10, $\mathrm{N}-\mathrm{CH}_{3}$ ] 62.9 [s, C-9, $\mathrm{CH}_{2} \mathrm{OH}$ ], 109.4 [t, C-7], 110.8 [q, C-3], 119.0 [t, C-5], 119.1 [t, C-4], 121.9 [t, C-6], 127.4 [t, C-2], 128.0 [q, C-3a], 137.3 [q, C-7a].

4.6.17. 3-(2-Hydroxyethyl)- $N$-benzylindole ${ }^{56}$ (3r). Purified by filtration through a short column of silica using $\mathrm{CH}_{2} \mathrm{Cl}_{2}$ as eluent, $90 \%$ yield. Obtained as an oil. Lit. ${ }^{57} 53^{\circ} \mathrm{C}$. IR $\left(\mathrm{cm}^{-1}\right)$ : 3368, 3056, 3029, 2927, 1614, 1496, 1467,
1454, 1357, 1333, 1177, 1044, 740, 700. Mass, $\mathrm{m} / \mathrm{z}(\%): 251$ $\left(\mathrm{M}^{+\cdot}, 20\right), 220$ (43), 129 (15), $102(10), 91(100), 65(15) .{ }^{1} \mathrm{H}$ NMR $\left(300 \mathrm{MHz}, \mathrm{CDCl}_{3}\right): \delta 1.73[1 \mathrm{H}, \mathrm{bs}, \mathrm{OH}], 3.00[2 \mathrm{H}, \mathrm{t}$, $\mathrm{H}-8, J=6.4 \mathrm{~Hz}], 3.85[2 \mathrm{H}, \mathrm{t}, \mathrm{H}-9, J=6.4 \mathrm{~Hz}], 5.22[2 \mathrm{H}, \mathrm{s}$, $\mathrm{H}-10, \mathrm{CH}_{2}$ benzyl], 6.96 [1H, s, H-2], 7.07-7.26 [8H, m, $\mathrm{CH}$ aromatic], $7.61[1 \mathrm{H}, \mathrm{bd}, \mathrm{H}-4, J=6-7 \mathrm{~Hz}] .{ }^{13} \mathrm{C} \mathrm{NMR}$

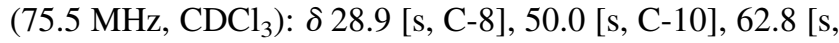
C-9, $\mathrm{CH}_{2} \mathrm{OH}$ ], 109.9 [t, C-7], 111.6 [q, C-3], 119.2 [t, C-5], 119.3 [t, C-4], 122.1 [t, C-6], 126.8 [t, C-12], $127.0[\mathrm{t}$, C-13], 127.8 [t, C-2], 128.3 [q, C-3a], 128.9 [t, C-14], 137.0 [q, C-11], 137.7 [q, C-7a].

4.6.18. 3-(N-Benzyl-2-hydroxyethyl)-7-ethylindole (3s). Purified by filtration through a short column of silica using $\mathrm{CH}_{2} \mathrm{Cl}_{2}$ as eluent, $82 \%$ yield. Obtained as an oil. ${ }^{1} \mathrm{H}$ NMR $\left(300 \mathrm{MHz}, \mathrm{CDCl}_{3}\right): \delta 1.28[3 \mathrm{H}, \mathrm{t}, \mathrm{H}-11, J=7.5 \mathrm{~Hz}], 2.88$ [2H, q, H-10, J=7.5 Hz], 3.06 [2H, t , H-8, J=6.4 Hz], 3.94 $[2 \mathrm{H}, \mathrm{t}, \mathrm{H}-9, J=6.4 \mathrm{~Hz}], 5.53\left[2 \mathrm{H}, \mathrm{s}, \mathrm{CH}_{2}\right.$ benzyl], $6.96[3 \mathrm{H}$, $\mathrm{m}, \mathrm{CH}$ aromatic], $7.02[1 \mathrm{H}, \mathrm{d}, \mathrm{H}-2, J=7.5 \mathrm{~Hz}], 7.12[1 \mathrm{H}, \mathrm{t}$, $\mathrm{CH}, J=7.5 \mathrm{~Hz}], 7.28[3 \mathrm{H}, \mathrm{m}, \mathrm{CH}$ aromatic $], 7.54[1 \mathrm{H}, \mathrm{d}$, $\mathrm{H}-4, J=7.5 \mathrm{~Hz}] .{ }^{13} \mathrm{C}$ NMR $\left(75.5 \mathrm{MHz}, \mathrm{CDCl}_{3}\right): \delta 16.2[\mathrm{p}$, C-11], 25.4 [s, C-10], 28.8 [s, C-8], 52.3 [s, C-12], 62.7 [s, C-9], 111.7 [q, C-3], 117.1 [t, CH], 119.8 [t, CH], 123.3 [t, $\mathrm{CH}], 125.7[\mathrm{t}, \mathrm{CH}], 127.5[\mathrm{t}, \mathrm{CH}], 127.9$ [q, C-3a], $128.9[\mathrm{t}$, $\mathrm{CH}$ ], 129.0 [t, CH], 129.6 [q, C-7], 134.9 [q, C-13], 139.6 [q, C-7a].

4.6.19. 3-(2-Hydroxyethyl)-7-ethylindole ${ }^{8 a}$ (3t). Purified by filtration through a short column of silica using $\mathrm{CH}_{2} \mathrm{Cl}_{2}$ as eluent, $78 \%$ yield. Obtained as an oil that solidified, $\mathrm{mp}$ 47-48 ${ }^{\circ} \mathrm{C}$. IR $\left(\mathrm{cm}^{-1}\right)$ : 3399, 3057, 2960, 2926, 2865, 1613, 1494, 1436, 1344, 1221, 1094, 1048, 1006, 820, 797, 747. ${ }^{1} \mathrm{H}$ NMR $\left(200 \mathrm{MHz}, \mathrm{CDCl}_{3}\right): \delta 1.39[3 \mathrm{H}, \mathrm{t}, \mathrm{H}-11, J=$ $7.6 \mathrm{~Hz}], 2.88[2 \mathrm{H}, \mathrm{q}, \mathrm{H}-10, J=7.6 \mathrm{~Hz}], 3.06[2 \mathrm{H}, \mathrm{t}, \mathrm{H}-8$, 6.3], $3.93[2 \mathrm{H}, \mathrm{t}, \mathrm{H}-9, J=6.3 \mathrm{~Hz}] 7.12[3 \mathrm{H}, \mathrm{m}, \mathrm{CH}], 7.51$ $[1 \mathrm{H}, \mathrm{dd}, \mathrm{CH}, J=1.6,7.0 \mathrm{~Hz}], 8.12[1 \mathrm{H}, \mathrm{bs}, \mathrm{NH}] .{ }^{13} \mathrm{C} \mathrm{NMR}$ $\left(50 \mathrm{MHz}, \mathrm{CDCl}_{3}\right): \delta 14.0[\mathrm{p}, \mathrm{C}-11], 24.2$ [s, C-10], $29.0[\mathrm{~s}$, C-8], 62.8 [s, C-9], 112.8 [q, C-3], 116.7 [t, CH], 119.9 [t, $\mathrm{CH}], 120.9$ [t, CH], 122.4 [t, CH], 126.8 [q, C], 127.3 [q, C], 135.5 [q, C-7a].

\subsection{Isolation of the intermediate diols (5a and $5 \mathrm{~m})$}

4.7.1. 3-(2-Hydroxypropyl)-3-hydroxy-2-oxindole (5a). Compound 5a was obtained when the aldol derivative $\mathbf{2 a}$ was treated with a deficiency of $\mathrm{BH}_{3}$.THF ( 2 mol equiv.) in anhydrous THF. The crude product was isolated as described in the general tryptophol synthesis procedure and the mixture of products was separated by silica gel chromatography. The tryptophol 3a and the diol 5a were separated using a solvent gradient of $\mathrm{CH}_{2} \mathrm{Cl}_{2} / \mathrm{EtOAc}$ (9:1, $8: 2,7: 3 \mathrm{v} / \mathrm{v}$ ) where $3 \mathbf{a}$ was eluted first in $72 \%$ yield followed by $5 \mathbf{a}$ in $21 \%$ yield, $\mathrm{mp} 194-195^{\circ} \mathrm{C}$. IR $\left(\mathrm{cm}^{-1}\right): 3417,3239$, 2972, 2934, 2909, 1708, 1624, 1475, 1189, 619. Mass, $\mathrm{m} / \mathrm{z}$ (\%): $207\left(\mathrm{M}^{+*}, 34\right), 189$ (11), 174 (28), 162 (27), 149 (79), 146 (100), 120 (81), 92 (38), 77 (17), 65 (32). ${ }^{1} \mathrm{H}$ NMR $\left(300 \mathrm{MHz}, \mathrm{CDCl}_{3}, \mathrm{DMSO}-\mathrm{d}_{6}\right): \delta 0.99 \quad[3 \mathrm{H}, \mathrm{d}, \mathrm{H}-10$, $J=6.2 \mathrm{~Hz}], 1.69[1 \mathrm{H}, \mathrm{dd}, \mathrm{H}-8, J=2.8,14.1 \mathrm{~Hz}], 2.03[1 \mathrm{H}$, dd, H-8 $, J=9.7,14.1 \mathrm{~Hz}], 3.97$ [1H, m, H-9], 4.44 [1H, d, C9-OH, $J=4.2 \mathrm{~Hz}], 6.05[1 \mathrm{H}, \mathrm{bs}, \mathrm{C} 3-\mathrm{OH}], 6.74[1 \mathrm{H}, \mathrm{d}$, $\mathrm{H}-7, J=7.7 \mathrm{~Hz}], 6.91[1 \mathrm{H}, \mathrm{td}, \mathrm{H}-5, J=1.2,7.7 \mathrm{~Hz}], 7.09$ $[1 \mathrm{H}, \mathrm{td}, \mathrm{H}-6, J=1.2,7.7 \mathrm{~Hz}], 7.19[1 \mathrm{H}, \mathrm{d}, \mathrm{H}-4, J=7.7 \mathrm{~Hz}]$, $9.90[1 \mathrm{H}, \quad$ bs, $\mathrm{NH}] .{ }^{13} \mathrm{C} \quad \mathrm{NMR} \quad\left(75.5 \mathrm{MHz}, \mathrm{CDCl}_{3}\right.$, 
DMSO-d ${ }_{6}$ ): $\delta 23.2$ [p, C-10], 44.5 [s, C-8], 61.9 [t, C-9], 74.2 [q, C-3], 108.5 [t, C-7], 120.3 [t, C-5], 122.6 [t, C-6], 127.6 [t, C-4], 131.0 [q, C-3a], 140.5 [q,C-7a], 178.6 [q, C-2]. Elemental analysis: $\mathrm{C}_{11} \mathrm{H}_{13} \mathrm{NO}_{3}$, calcd: $\mathrm{C}$ : $63.76, \mathrm{H}$ : 6.32, N: 6.76, obs.: $\mathrm{C}: 63.93, \mathrm{H}: 6.11, \mathrm{~N}: 6.20$. HRMS: $\mathrm{C}_{11} \mathrm{H}_{13} \mathrm{NO}_{3}$, calcd: 207.0896, obs.: 207.0872.

4.7.2. 3-(2-Phenyl-2-hydroxyethyl)-3-hydroxy- $N$-benzyl2-oxindole $(\mathbf{5 m})$. Compound $\mathbf{5 m}$ was obtained in a similar manner to compound $\mathbf{5 a}$ when the aldol derivative $\mathbf{2 m}$ was treated with a deficiency of $\mathrm{BH}_{3} \cdot \mathrm{THF}$. The products were purified by silica gel column chromatography using a $\mathrm{CH}_{2} \mathrm{Cl}_{2} /$ EtOAc gradient $(9: 1,8: 2,7: 3 \mathrm{v} / \mathrm{v})$ as eluent. The tryptophol $\mathbf{3 m}$ was eluted first in $63 \%$ yield followed by compound $5 \mathrm{~m}, 25 \%$ yield, $\mathrm{mp} 143-144^{\circ} \mathrm{C}$. IR $\left(\mathrm{cm}^{-1}\right)$ : 3443, 3360, 3030, 2940, 1694, 1615, 1468, 1371, 1351, 1176, 1056, 756, 699. Mass, $m / z(\%): 359\left(\mathrm{M}^{+*}, 1\right), 252(2)$, 239 (60), 162 (8), 161 (16), 146 (13), 133 (6), $105(7), 92$ (11), 91 (100), 77 (19), 65 (17). ${ }^{1} \mathrm{H}$ NMR (200 MHz, $\mathrm{CDCl}_{3}$ ): $\delta 1.96[1 \mathrm{H}, \mathrm{dd}, \mathrm{H}-8, J=2.5,15.5 \mathrm{~Hz}], 2.59[1 \mathrm{H}, \mathrm{dd}$, $\left.\mathrm{H}-8^{\prime}, J=11.0,15.1 \mathrm{~Hz}\right], 3.40[1 \mathrm{H}, \mathrm{d}, \mathrm{C} 9-\mathrm{OH}, J=2.5 \mathrm{~Hz}$, $4.84[1 \mathrm{H}, \mathrm{d}, \mathrm{H}-14, J=15.7 \mathrm{~Hz}], 4.95\left[1 \mathrm{H}, \mathrm{d}, \mathrm{H}-14^{\prime}, J=\right.$ $15.7 \mathrm{~Hz}], 5.45[1 \mathrm{H}, \mathrm{sl}, \mathrm{C} 3-\mathrm{OH}], 5.50[1 \mathrm{H}, \mathrm{dd}, \mathrm{H}-9, J=2.5$, $11.0 \mathrm{~Hz}], 6.69[1 \mathrm{H}, \mathrm{dd}, \mathrm{H}-7, J=0.6,7.7 \mathrm{~Hz}], 7.03[1 \mathrm{H}, \mathrm{td}$, $\mathrm{H}-5, J=1.5,7.7 \mathrm{~Hz}], 7.17[1 \mathrm{H}, \mathrm{td}, \mathrm{H}-6, J=1.5,7.7 \mathrm{~Hz}]$, $7.2-7.4[11 \mathrm{H}, \mathrm{m}, \mathrm{CH}$ aromatic $] .{ }^{13} \mathrm{C} \mathrm{NMR}(50 \mathrm{MHz}$, $\left.\mathrm{CDCl}_{3}\right): \delta 43.9$ [s, C-8], 45.9 [s, C-14], 70.8 [t, C-9, CHOH], 76.2 [q, C-3, COH], 109.6 [t, C-7], 123.4 [t, C-5], 123.9 [t, C-6], 125.7 [t, C-16], 127.4 [t, C-17], 127.9 [t, C-11], 127.9 [t, C-12], 128.8 [t, C-18], 129.0 [t, C-4], 129.7 [t, C-13], 131.2 [q, C-3a], 135.7 [q, C-15], 142.1 [q, C-10], 144.1 [q, C-7a], 178.5 [q, C-2, $\mathrm{C}=\mathrm{O}$, amide]. Elemental analysis: $\mathrm{C}_{23} \mathrm{H}_{21} \mathrm{NO}_{3}$, calcd: C: 76.86, $\mathrm{H}: 5.89, \mathrm{~N}: 3.90$, obs.: C: 76.90, H: 5.72, N: 3.79 .

\subsection{General experimental procedure for the synthesis of the dioxindole diols (5b and $5 \mathrm{~m}$ )}

The respective aldol derivatives $(3.0 \mathrm{mmol})$ were solubilised/ suspended in anhydrous THF $(10 \mathrm{ml})$ and cooled on an ice water bath. A solution of $\mathrm{BH}_{3} \cdot \mathrm{THF}$ ( 1 mol equiv.) was slowly added to the reaction mixtures. The substrate was observed to completely solubilise after a couple of minutes. The reactions were left stirring in the cooling bath for an hour after which time TLC (ethyl acetate/hexane) revealed the consumption of the substrate with the formation of a product of similar polarity and the absence of the respective tryptophol.

The crude product was isolated by quenching the reaction mixture with saturated aqueous $\mathrm{NH}_{4} \mathrm{Cl}(30 \mathrm{ml})$ and extraction with EtOAc $(2 \times 25 \mathrm{ml})$. The organic phase was washed once with saturated aqueous $\mathrm{NH}_{4} \mathrm{Cl}$, dried over $\mathrm{Na}_{2} \mathrm{SO}_{4}$, and evaporated under reduced pressure. The crude products were characterized by IR, ${ }^{1} \mathrm{H}$ and ${ }^{13} \mathrm{C} \mathrm{NMR}$.

4.8.1. 3-Hydroxy-3-(2-hydroxypropyl)- $N$-methyl-2-oxindole (5b). Yield 94\%, diastereomeric ratio 2:1; mp 103$110^{\circ} \mathrm{C}$. IR $\left(\mathrm{cm}^{-1}\right): 3431,3338,3059,2960,2937,1706$, $1616,1472,1382,1356,1300,1113,755 .{ }^{1} \mathrm{H}$ NMR $\left(200 \mathrm{MHz}, \mathrm{CDCl}_{3}\right): \delta 1.18$ [major $3 \mathrm{H}, \mathrm{d}, \mathrm{H}-10, J=$ $4.1 \mathrm{~Hz}$ ], 1.21 [minor $3 \mathrm{H}, \mathrm{d}, \mathrm{H}-10, J=3.7 \mathrm{~Hz}$ ], 1.73 [minor $1 \mathrm{H}, \mathrm{dd}, \mathrm{H}-8, J=2.6,14.9 \mathrm{~Hz}$ ], 1.80 [minor $1 \mathrm{H}, \mathrm{dd}, \mathrm{H}-8$,
$J=2.1,14.9 \mathrm{~Hz}$ ], 2.07 [major $1 \mathrm{H}, \mathrm{dd}, \mathrm{H}-8, \quad J=10.1$, $14.8 \mathrm{~Hz}$ ], 2.23 [major $1 \mathrm{H}$, dd, H-8, $J=10.7,14.8 \mathrm{~Hz}$ ], 3.16 [minor $3 \mathrm{H}, \mathrm{s}, \mathrm{N}-\mathrm{CH}_{3}$ ], 3.18 [major $3 \mathrm{H}, \mathrm{s}, \mathrm{N}-\mathrm{CH}_{3}$ ], 4.44 [both isomers $1 \mathrm{H}, \mathrm{m}, \mathrm{H}-9], 6.82[1 \mathrm{H}, \mathrm{t}, J=7.5 \mathrm{~Hz}], 7.11$ $[1 \mathrm{H}, \mathrm{m}], 7.30-7.48[2 \mathrm{H}, \mathrm{m}] .{ }^{13} \mathrm{C} \mathrm{NMR}\left(50 \mathrm{MHz}, \mathrm{CDCl}_{3}\right): \delta$ 22.8, $23.2\left[\mathrm{CH}_{3}\right], 26.4,26.5\left[\mathrm{CH}_{3}\right], 45.1,45.2\left[\mathrm{CH}_{2}\right], 64.6$, $64.8[\mathrm{CH}], 76.3,76.5[\mathrm{C} 3], 108.5,108.8[\mathrm{CH}], 123.4[\mathrm{CH}]$, 124.0, 124.4 [CH], 129.7, 129.8 [CH], 131.0, 131.4 [C3a], 142.9 [C7a], 178.5, $178.7[\mathrm{C}=\mathrm{O}]$.

4.8.2. 3-Hydroxy-3-(2-hydroxy-2-phenylethyl)- $N$-benzyl2-oxindole $(\mathbf{5 m})$. Yield $97 \%$, diastereomeric ratio $2: 1 ; \mathrm{mp}$ $120-125^{\circ} \mathrm{C}$. IR $\left(\mathrm{cm}^{-1}\right): 3347,3030,2940,1697,1614$, 1468, 1371, 1351, 1176, 755, 699. ${ }^{1} \mathrm{H}$ NMR $(200 \mathrm{MHz}$, $\mathrm{CDCl}_{3}$ ): $\delta 1.98$ [major $1 \mathrm{H}, \mathrm{dd}, \mathrm{H}-8, J=2.5,15.0 \mathrm{~Hz}$ ], 2.05 [minor $1 \mathrm{H}$, dd, H-8, $J=2.5,14.9 \mathrm{~Hz}$ ], 2.49 [minor $1 \mathrm{H}$, dd, $\mathrm{H}-8^{\prime}, J=10.5,14.9 \mathrm{~Hz}$ ], 2.61 [major $1 \mathrm{H}, \mathrm{dd}, \mathrm{H}-8^{\prime}, J=11.1$, $15.0 \mathrm{~Hz}$ ], 4.76 [minor $1 \mathrm{H}, \mathrm{d}, \mathrm{NCH}_{2}$ benzylic, $J=15.5 \mathrm{~Hz}$ ], 4.86 [major $1 \mathrm{H}, \mathrm{d}, \mathrm{NCH}_{2}$ benzylic, $J=15.6 \mathrm{~Hz}$ ], 4.96 [major $1 \mathrm{H}, \mathrm{d}, \mathrm{NCH}_{2}$ benzylic, $J=15.6 \mathrm{~Hz}$ ], 5.32 [minor $1 \mathrm{H}$, dd, $\mathrm{H}-9, J=2.5,10.5 \mathrm{~Hz}$ ], 5.49 [major $1 \mathrm{H}, \mathrm{dd}, \mathrm{H}-9, J=2.5$, $11.1 \mathrm{~Hz}], 6.6-7.6[14 \mathrm{H}, \mathrm{CH}$ aromatic $] .{ }^{13} \mathrm{C} \mathrm{NMR}(50 \mathrm{MHz}$, $\left.\mathrm{CDCl}_{3}\right): \delta 43.9,44.1\left[\mathrm{CH}_{2}\right], 45.8,46.0\left[\mathrm{CH}_{2}\right], 70.7,71.3$ $[\mathrm{CH}], 76.4,76.6[\mathrm{C} 3], 109.6,109.9[\mathrm{CH}], 123.4,123.5$ $[\mathrm{CH}], 123.9,124.5[\mathrm{CH}], 125.7,126.1[\mathrm{CH}], 127.4[\mathrm{CH}]$, $127.85,127.92[\mathrm{CH}], 128.68,128.73[\mathrm{CH}], 129.00,129.04$ $[\mathrm{CH}], 129.7,129.9[\mathrm{CH}], 130.7,131.2[\mathrm{C}], 135.5,135.7[\mathrm{C}]$, $142.1[\mathrm{C}], 143.8,144.1[\mathrm{C}], 178.2,178.5[\mathrm{C}=\mathrm{O}]$.

\section{Acknowledgements}

We would like to thank Professors Vitor F. Ferreira (Universidade Federal Fluminensce, Rio de Janeiro), Francis J. Schmitz (University of Oklahoma) for the FAB mass spectra, Marcus Eberlin (University of Campinas, São Paulo) for HRMS and Mario Vasconcellos (Núcleo de Pesquisas em Produtos Naturais, Universidade Federal do Rio de Janeiro) for the sample of 7-ethylisatin. In addition, we would like to thank the $\mathrm{CNPq}$ (Brazilian National Research Council), and the Fundação à Apoio de Pesquisa do Estado de Rio de Janeiro, FAPERJ. SJG also acknowledges the Fundação Fiocruz, Farmanguinhos (PAPES II) for financial support.

\section{References}

1. (a) Sundberg, R. J. Indoles. Academic: San Diego, 1996. (b) Wagaw, S.; Yang, B. H.; Buchwald, S. L. J. Am. Chem. Soc. 1998, 120, 6621-6622. (c) Peat, A. J.; Aoki, K.; Buchwald, S. L. J. Am. Chem. Soc. 1998, 120, 3068-3073. (d) Wagaw, S.; Yang, B. H.; Buchwald, S. L. J. Am. Chem. Soc. 1999, 121, 10251-10263. (e) Gribble, G. W. J. Chem. Soc. Perkin Trans. 1 2000, 1045-1075. (f) Butin, A. V.; Stroganova, T. A.; Lodina, I. V.; Krapivin, G. D. Tetrahedron Lett. 2001, 42, 2031-2033. (g) Klapars, A.; Antilla, J. C.; Huang, X. H.; Buchwald, S. L. J. Am. Chem. Soc. 2001, 123, 7727-7729. (h) Miyata, O.; Kimura, Y.; Naito, T. Synthesis 2001, 1635-1638. (i) Penoni, A.; Volkmann, J.; Nicholas, K. M. Org. Lett. 2002, 4, 699-701. (j) Penoni, A.; Nicholas, K. M. Chem. Commun. 2002, 484-485. 
2. (a) Ehrlich, F. Ber. 1909, 45, 883-889, Chem. Abstr. 6, $2427^{2}$. (b) Fenn, P.; Durbin, R. D.; Kuntz, J. E. Phytochemistry 1977, 16, 899-901. (c) Lacan, G.; Magnus, V.; Jericevic, B.; Kunst, L.; Iskric, S. Plant Physiol. 1984, 76, 889-893. (d) Lacan, G.; Magnus, V.; Simaga, S.; Iskric, S.; Hall, P. J. Plant Physiol. 1985, 78, 447-454. (e) Ayer, W. A.; Browne, L. M.; Feng, M.-C.; Orszanska, H.; Saeedi-Ghomi, H. Can. J. Chem. 1986, 64, 904-909. (f) Kawashima, A.; Seto, H.; Kato, M.; Yasuda, A.; Uchida, K.; Otake, N. J. Antibiot. 1986, 39, 1495-1497, Chem. Abstr. 106, 29752q. (g) Sugawara, F.; Strobel, G. A. Phytochemistry 1987, 26, 1349-1352. (h) Shin, M.; Shinguu, T.; Sano, K.; Umezawa, C. Chem. Pharm. Bull. 1991, 39, 1792-1795. (i) Martens, D. A.; Frankenberger, W. T. J. Soil Sci. 1993, 155, 263-271, Chem. Abstr. 119, 71587h. (j) Mantle, P. G.; Weedon, C. M. Phytochemistry 1994, 36, 1209-1218.

3. Fernando, I. N.; Francis, P. L.; Smith, I. J. Neural. Transm. 1983, 56, 33-41.

4. (a) Vincendeau, P.; Lesthelle, S.; Bertazzo, A.; OkomoAssoumou, M. C.; Allegri, G.; Costa, C. V. Adv. Exp. Med. Biol. 1999, 467, 525-531. (b) Cornford, E. M.; Crane, P. D.; Braun, L. D.; Bocash, W. D.; Nyerges, A. M.; Oldendorf, W. H. J. Neurochem. 1981, 36, 1758-1765.

5. Humber, L. G.; Ferdinandi, E.; Demerson, C. A.; Ahmed, S.; Shah, U.; Mobilio, D.; Sabatucci, J.; Lange, B. D.; Labbadia, F.; Hughes, P.; Virgilio, J. D.; Neuman, G.; Chau, T. T.; Weichman, B. M. J. Med. Chem. 1988, 31, 1712-1719.

6. Katz, A. H.; Demerson, C. A.; Shaw, C. C.; Asselin, A. A.; Humber, L. G.; Conway, K. M.; Gavin, G.; Guinosso, C.; Jensen, N. P.; Mobilio, D.; Noureldin, R.; Schmid, J.; Shah, U.; Engen, D. V.; Chau, T. T.; Weichman, B. M. J. Med. Chem. 1988, 31, 1244-1250.

7. Jackson, R. W. J. Biol. Chem. 1930, 88, 659-662, Chem. Abstr. 25, 514.

8. (a) Demerson, C. A.; Humber, L. G.; Philipp, A. H.; Martel, R. R. J. Med. Chem. 1976, 19, 391-395. (b) Upjohn Co. British Patent 778,823, 10 July 1957; Chem. Abstr. 52, P1266a.

9. (a) Eiter, K.; Svierak, O.; Monatsh, . Monatsh. 1952, 1453-1476. (b) Nakazaki, M. Bull. Chem. Soc. Jpn 1959, 32, 588-593. (c) Bergman, J.; Bäckvall, J. E. Tetrahedron 1975, 31, 2063-2073. (d) Mobilio, D.; Humber, L. G.; Katz, A. H.; Demerson, C. A.; Hughes, P.; Brigance, R.; Conway, K.; Shah, U.; Williams, G.; Labbadia, F.; Lange, B. D.; Asselin, A.; Schmid, J.; Newburger, J.; Jensen, N. P.; Weichman, B. M.; Chau, T.; Neuman, G.; Wood, D. D.; Engen, D. V.; Taylor, N. J. Med. Chem. 1988, 31, 2211-2217.

10. Freter, K. Liebigs Ann. Chem. 1978, 1357-1364.

11. Audia, J. E.; Colocci, N. Tetrahedron Lett. 1991, 32, 3779-3782.

12. (a) Grandberg, I. I.; Kost, A. N.; Terentev, A. P. Zh. Obshchei Khim. 1957, 27, 3342-3345, Chem. Abstr. 52, 9071 i. (b) Grandberg, I. L.; Tokmakov, G. P. Simp Khim. Tekhnol. Geterotsikl. Soedin. Goryuch Iskop 1973, 2, 53-54, Chem. Abstr. 86, 16493z. (c) McKittrick, B.; Failli, A.; Steffan, R. J.; Soll, R. M.; Hughes, P. J. Heterocycl. Chem. 1990, 27, 2151-2163. (d) White, J. D.; Yager, K. M.; Yakura, T. J. Am. Chem. Soc. 1994, 116, 1831-1838. (e) Lajsic, S.; Cetkovic, G.; Popsavin, M.; Popsavin, V.; Miljkovic, D. Collect. Czech. Chem. Commun. 1996, 61, 298.

13. (a) Oddo, B.; Cambieri, F. Gazz. Chim. Ital. 1939, 69, 19-24. (b) Robinson, R. A. US Patent 2,908,691, 13 October, 1959; Chem. Abstr. 56, 3455d. (c) Julia, M.; Le Goffic, F.; Igolen, J.;
Baillarge, M. Tetrahedron Lett. 1969, 1569-1571. (d) Ghosh, A.; Wang, W.; Freeman, J. P.; Althaus, J. S.; Von Voigtlander, P. F.; Scahill, T. A.; Mizsak, S. A.; Szmuszkovicz, J. Tetrahedron 1991, 47, 8653-8662.

14. (a) Gribble, G. W.; Johnson, D. A. Tetrahedron Lett. 1987, 28 , 5259-5262. (b) Griffen, E. J.; Roe, D. G.; Snieckus, V. J. Org. Chem. 1995, 60, 1484-1485. (c) Amat, M.; Coll, M. D.; Passarella, D.; Bosch, J. Tetrahedron: Asymmetry 1996, 7, 2775-2778. (d) Amat, M.; Pshenichnyi, G.; Bosch, J.; Molins, E.; Miravitlles, C. Tetrahedron: Asymmetry 1996, 7, 3091-3094.

15. Johnson, H. E. US Patent 3,197,479, 27 July, 1965; Chem. Abstr. 63, P13217f.

16. (a) Kotsuki, H.; Nishiuchi, M.; Kobayashi, S.; Nishizawa, H. J. Org. Chem. 1990, 55, 2969-2972. (b) Kotsuki, H.; Hayashida, K.; Shimanouchi, T.; Nishizawa, H. J. Org. Chem. 1996, 61, 984-990.

17. Kotsuki, H.; Teraguchi, M.; Shimomoto, N.; Ochi, M. Tetrahedron Lett. 1996, 37, 3727-3730.

18. (a) Ito, Y.; Kobayashi, K.; Saegusa, T. J. Am. Chem. Soc. 1977, 99, 3532-3534. (b) Ito, Y.; Kobayashi, K.; Seko, N.; Saegusa, T. Bull. Chem. Soc. Jpn 1984, 57, 73-84.

19. (a) Zhang, D.; Liebeskind, L. S. J. Org. Chem. 1996, 61, 2594-2595. (b) Bailey, W. F.; Jiang, X.-L. J. Org. Chem. 1996, 61, 2596-2597.

20. Dong, Y.; Busacca, C. A. J. Org. Chem. 1997, 62, 6464-6465.

21. (a) da Silva, J. F. M.; Garden, S. J.; Pinto, A. C. J. Braz. Chem. Soc. 2001, 12, 273-324. (b) Popp, F. D. Adv. Heterocycl. Chem. 1975, 18, 1-59.

22. Tacconi, G. Farmaco Ed. Sci. 1965, 20, 891-901, Chem. Abstr. 64, 11151d.

23. David, S.; Doucet, M. C. Bull. Soc. Chim. Fr. 1967, 6, 2152-2154, Chem. Abstr. 68, 59395q.

24. (a) Bergman, J. Tetrahedron 1971, 27, 1167-1171. (b) Bergman, J. Acta Chem. Scand. 1971, 1277-1280.

25. Soll, R. M.; Guinosso, C.; Asselin, A. J. Org. Chem. 1988, 53, 2844-2847.

26. Pinto, A. C.; Silva, F. S. Q.; Silva, R. B. Tetrahedron Lett. 1994, 35, 8923-8926.

27. Torres, J. C.; Garden, S. J.; Pinto, A. C.; Boechat, N.; da Silva, F. Tetrahedron 1999, 55, 1881-1892.

28. Sirowej, H.; Khan, S. A.; Pleininger, H. Synthesis 1972, 84.

29. Wierenga, W.; Griffin, J.; Warpehoski, M. A. Tetrahedron Lett. 1983, 24, 2437-2440.

30. (a) Jiang, B.; Smallheer, J. M.; Amaral-Ly, C.; Wuonola, M. A. J. Org. Chem. 1994, 59, 6823-6827. (b) Cushing, T. D.; SanzCervera, J. F.; Williams, R. M. J. Am. Chem. Soc. 1996, 118, $557-579$.

31. McEvoy, F. J.; Allen, G. J. J. Org. Chem. 1973, 38, $3350-3352$.

32. (a) Chou, S.-Y.; Tseng, C.-L.; Chen, S- F. Heterocycles 1999 , 51, 1527-1541. (b) Costa, P. R. R.; Cabral, L. M.; Alencar, K. G.; Schmidt, L. L.; Vasconcellos, M. L. A. A. Tetrahedron Lett. 1997, 38, 7021-7024.

33. Ezquerra, J.; Pedregal, C.; Lamas, C.; Pastor, A.; Alvarez, P.; Vaquero, J. J. Tetrahedron 1997, 53, 8237-8248.

34. Braude, F.; Lindwall, H. G. J. Am. Chem. Soc. 1933, 55, 325-327.

35. Zweifel, G.; Brown, H. C. Org. React. 1963, 13, 1-54.

36. Berger, J. G. Synthesis 1974, 508-510.

37. The cyclohexanone aldol product ( $\mathbf{2} \mathbf{j})$ was obtained as a $3: 2$ mixture of inseperable diastereoisomers when the substrate was prepared in $\mathrm{MeOH}$. Use of EtOAc as the solvent for 
preparation of $\mathbf{2} \mathbf{j}$ gave a 4:1 mixture of diastereoisomers. All reduction experiments were performed using these mixtures and all reduction experiments irrespective of the inital diastereomeric excess resulted in the same diastereomeric excess of tryptophols (trans/cis, 8:1).

38. (a) Brown, H. C.; Bigley, D. B. J. Am. Chem. Soc. 1961, 83, 3166-3167. (b) Brown, H. C.; Varma, V. J. Am. Chem. Soc. 1966, 88, 2871.

39. For a review on directed reactions consult: Hoveyda, A. H.; Evans, D. A.; Fu, G. C. Chem. Rev. 1993, 93, 1307-1370.

40. (a) We are currently unaware of any example of a diastereoselective borane reduction of a tertiary $\beta$-hydroxyketone. On the other hand, many examples of selective reductions of secondary $\beta$-hydroxyketones using the Evans procedure have been described. Reaction of the tertiary hydroxyl group with an electrophile is possible, for example the tertiary hydroxyl group can be tosylated Autrey, R. L.; Tahk, F. C. Tetrahedron 1967, 23, 901-917, Therefore the first step in the mechanism can be depicted as the reaction of $\mathrm{BH}_{3}$. THF with the hydroxyl group to form a borohydride ester. (b) Ravikumar, K. S.; Sinha, S.; Chandrasekaran, S. J. Org. Chem. 1999, 64, 5841-5844. (c) Keck, G. E.; Wager, C. A. Org. Lett. 2000, 2, 2307-2309. (d) Keck, G. E.; Wager, C. A.; Sell, T.; Wager, T. T. J. Org. Chem. 1999, 64, 2172-2173. (e) Bartoli, G.; Bosco, M.; Bellucci, M. C.; Dalpozzo, R.; Marcantoni, E.; Sambri, L. Org. Lett. 2000, 2, 45-47.

41. (a) Evans, D. A.; Chapman, K. T.; Carreira, E. M. J. Am. Chem. Soc. 1988, 110, 3560-3578. (b) Evans, D. A.; Chapman, K. T. Tetrahedron Lett. 1986, 27, 5939-5942.

42. This chemistry is currently being investigated and the results will be reported in due course.

43. Tang, Y.-Q.; Sattler, I.; Thiericke, R.; Grabley, S.; Feng, X.-Z. Proceedings of ECSOC-3 [and] Proceedings of ECSOC-4, 1999-2000; Chem. Abstr. 134, 307709.
44. Bogavac, M.; Arsenijevic, L.; Pavlov, S.; Arsenijevic, V. Arh. Farm. 1985, 35, 99-103, Chem. Abstr. 108, $204444 f$.

45. The relative configuration of the 1,3-diol (compounds $\mathbf{5}$ ) is presently unknown. Evans has proposed that internal hydride delivery yields anti-diols whilst external hydride delivery to chelated substrates yields syn-diols Evans, D. A.; Chapman, K. T.; Carreira, E. M. J. Am. Chem. Soc. 1988, 110, 3560-3578.

46. (a) Brown, H. C.; Heim, P.; Yoon, N. M. J. Org. Chem. 1972, 37, 2942-2950. (b) Brown, H. C.; Heim, P. J. Org. Chem. 1973, 38, 912-916. (c) Lane, C. F. Chem. Rev. 1976, 76, 773-799. (d) Alcântara, A. F. C.; Barroso, H. S.; Piló-Veloso, D. Quim. Nova 2002, 25, 300-311.

47. (a) Garden, S. J.; Torres, J. C.; Ferreira, A. A.; Silva, R. B.; Pinto, A. C. Tetrahedron Lett. 1997, 38, 1501-1504. (b) Garden, S. J.; Torres, J. C.; da Silva, L. E.; Pinto, A. C. Synth. Commun. 1998, 28, 1679-1689.

48. Popp, F. D.; Parson, R.; Donigan, B. E. J. Pharm. Sci. 1980, 69, 1235-1237.

49. Kamano, Y.; Zhang, H.-p.; Ichihara, Y.; Kizu, H.; Komiyama, K.; Pettit, G. R. Tetrahedron Lett. 1995, 36, 2783-2784.

50. Popp, F. D.; Donigan, B. E. J. Pharm. Sci. 1979, 68, 519-520.

51. Popp, F. D.; Pajouhesh, H. J. Pharm. Sci. 1982, 71, 1052-1054, Chem. Abstr. 98, 16536p.

52. Schaefer, J. P.; Kulkarni, K. S.; Costin, R.; Higgins, J.; Honig, L. M. J. Heterocycl. Chem. 1970, 7, 607-613.

53. Pajouhesh, H.; Parson, R.; Popp, F. D. J. Pharm. Sci. 1983, 72, 318-321, Chem. Abstr. 98, 197937p.

54. Heath-Brown, B.; Philpott, P. G. J. Chem. Soc. 1965, 7165-7168, Chem. Abstr. 64, 5032f.

55. Julia, M.; Igolen, H.; Lenzi, J. Bull. Soc. Chim. Fr. 1966, 7 , 2291-2295, Chem. Abstr. 65, 16928h.

56. Grandberg, I. I.; Tokmakov, G. P. Khim. Geterotsikl. Soedin. 1974, 1083-1084, Chem. Abstr. 81, 169389s.

57. Julia, M.; Sliwa, H.; Caubere, P. Bull. Soc. Chim. Fr. 1966, 3359-3361, Chem. Abstr. 66, 45920d. 